\title{
Article
}

\section{Analysing Regionalism within International Law and Relations: The Shanghai Cooperation Organisation as a Grossraum?}

Salter, Michael and Yin, Yinan

Available at http://clok.uclan.ac.uk/13371/

Salter, Michael and Yin, Yinan (2014) Analysing Regionalism within International Law and Relations: The Shanghai Cooperation Organisation as a Grossraum? Chinese Journal of International Law, 13 (4). pp. 819-877. ISSN $1540-1650$

It is advisable to refer to the publisher's version if you intend to cite from the work. http://dx.doi.org/10.1093/chinesejil/jmu044

For more information about UCLan's research in this area go to http://www.uclan.ac.uk/researchgroups/ and search for <name of research Group>.

For information about Research generally at UCLan please go to http://www.uclan.ac.uk/research/

All outputs in CLoK are protected by Intellectual Property Rights law, including Copyright law. Copyright, IPR and Moral Rights for the works on this site are retained by the individual authors and/or other copyright owners. Terms and conditions for use of this material are defined in the policies page.

\section{CLoK}

Central Lancashire online Knowledge www.clok.uclan.ac.uk

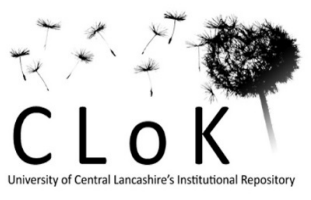




\begin{tabular}{|l|l|}
\hline Journal: & CJILAW \\
\hline Article id: & JMU044 \\
\hline
\end{tabular}

\begin{tabular}{|l|l|}
\hline Colour on-line figure & None \\
\hline Colour print figures & None \\
\hline
\end{tabular}

The following queries have arisen while collating the corrections. Please check and advise us on the below queries. 


\title{
Analysing Regionalism within International Law and Relations: The Shanghai Cooperation Organisation as a Grossraum?
}

\author{
Michael Salter* and Yinan Yin
}

\begin{abstract}
This article argues for new way of addressing contemporary international law that is more adequate to both vital dynamic trends towards "regionalism" within international law, relations and politics, and the emergent possibility of a far more pluralistic "multipolar" legal order that-in both theory and practice - contrasts markedly with US-dominated hegemonic modes of regulation and high-handed unilateralism. To advance our argument, we draws upon classic Schmittian forms of Grossraum theory concerned to adapt traditional state-centric and purely horizontal conceptual types of international law interpretations to a form of international relations structured around regional ensembles, such as the European Union, NATO, the African Union, and the Shanghai Cooperation Organisation (SCO). These historical trends are emerging out of an encompassing contemporary developmental tendency, including the decline in the traditional nation state posited as having equal status, and both the proliferation of new regional bodies and the strengthening of existing ones. Arguably, the emergence of the SCO from 2001 signals a new phase in multilateralism in the post-Cold War period that, when treated as a case study, allows us to "test out" the credibility of key aspects of Grossraum theory.
\end{abstract}

“... [T] he world will have to accommodate itself to the emergence of a few great multi-national units in which power will be mainly

* Michael Salter is Professor of Law, Lancashire Law School, University of Central Lancashire, UK; Yinan Yin is an associate lecturer at Lancashire Law School. The paper was completed on 9 November 2014. The websites cited were current as of this date unless otherwise noted. 
concentrated. Culturally, these units may best be called civilizations: there are distinctively British, American, Russian and Chinese civilizations, none of which stops short at national boundaries in the old sense. Economically, the term Grossraum invented by German geopoliticians seems the most appropriate". E. H. Carr ${ }^{1}$

"Are different spheres of US, European, Chinese and Russian Großräumen really to be preferred to a unipolar world?"Stuart Elden ${ }^{2}$

"The SCO [...] is one of China's most ambitious contributions to global governance, embodying a "new international relations" that rejects U.S. unilateralism and, according to its official mission statement, promotes cooperation based on principles of sovereign non-interference and cultural diversity. Accordingly, the success of the SCO, how the organization is treated by its other member countries, and how it interacts with other multilateral organizations and external actors operating in the region are also important indicators of the current scope and depth of China's growing global power and influence". Alexander Cooley ${ }^{3}$

\section{Introduction}

1. We argue that we now need a new way of thinking about international law that exhibits a principle of territorial distinction and self-restriction, ${ }^{4}$ which is more adequate to both vital dynamic trends towards "regionalism" within international law, relations and politics, and the emergent possibility of a pluralistic multipolar legal order. ${ }^{5}$ These

1 Edward. H. Carr, Nationalism and After (1945), 52.

2 Stuart Elden, Reading Schmitt geopolitically Nomos, territory and Großraum, 161 Radical Philosophy (2010), 24.

3 Alexander Cooley, Great Games, Local Rules: The New Great Power Contest in Central Asia (2012), 75.

4 Territory in the sense meant here remains a bounded space under the control of a group. Elden, above n.2, 22.

5 There has clearly been a regional delimitation of international law into specialised technical regimes in many fields including trade, human rights and the environment. See e.g. Mireille Delmas-Marty, Trois défis pour un droit mondial (1998); the various essays in Michael Byers (ed.) The Role of Law in International Politics, 2000; Martti Koskenniemi, International Law and Hegemony. A Reconfiguration, 17(2) Cambridge Review of International Affairs (2004), 197-218. The US National Intelligence Council's 2010 Report on global governance devotes an entire annex to the rise of regionalism. See US National Intelligence Council and EU Institute of Security Studies, Global Governance 2025: At a Critical Juncture, 2010 (www.iss.europa.eu/ uploads/media/Global__Governance_2025.pdf). See also Roberto Bouzas, Mercosur Ten Years After: Learning Process or Deja-Vu?, in: Joseph Tulchin (ed.) Paths to Regional Integration: The Case of Mercosur, 115-34 (www.wilsoncenter.org/ publication/paths-to-regional-integration-the-case-mercosur). See also, Geert Laporte and James Mackie (eds.) Building the African Union: An Assessment of Past Progress 
trends are emerging out of an encompassing contemporary developmental tendency, including both the proliferation of new regional bodies and the strengthening of existing ones. ${ }^{6}$ Arguably, China's role in the establishment and promotion of Shanghai Cooperation Organisation (SCO) signals a new phase in this state's interpretation of the importance of multilateralism in the post-Cold War period. In response to such trends, the first question raised under the Fourth European Society for International law (ESIL) Research Forum panel in 2007] on "fragmentation of international law" was: "can regional fragmentation be considered as new Grossräume?"

2. This article first summarises this idea of Grossraum in terms of its classic formulation by Carl Schmitt. It then tests out its cogency and makes a series of critical points by reference to the empirical details of a major case study: that of the Shanghai Cooperation Organisation (SCO). Our study thus engages in a close analysis of a particular model of regionalism within international law and relations: Grossraum theory, which one of the present authors has recently developed and revised from the earlier and, in many places, problematic international law writings of Carl Schmitt. ${ }^{7}$ These increasingly influential

and Future Prospects of the African Union's Institutional Architecture, European Centre for Development Policy Management (ECDPM) Report No. 18 (www. asean.org/asean/about-asean/history/item/political-achievement).

6 For example, the Southern Common Market Group, MERCOSUR, African Union, Arab League, ASEAN and Gulf Council. See Julie Boland, Ten Years of the Shanghai Cooperation Organization: A Lost Decade? A Partner for the U.S.? Brookings Institute Paper (2011), 23. For recent studies of the tendencies towards regionalism, see, Yoshinobu Yamamoto (ed.) Globalism, Regionalism and Nationalism (1999); Edward D. Mansfield and Helen V. Milner, The new wave of regionalism, 3(53) International Organization (1999), 589-627; Louise Fawcett, Exploring regional domains: a comparative history of regionalism, 3(80) International Affairs (2004), 429-446; Raimo Vayrynen, Regionalism: old and new, 5(1) International Studies (2003), 25-52.

7 Schmitt's controversial analysis of Grossraum and related spatial issues is largely contained in his articles brought together in a post-war collection by Gerhart Maschke (ed.) Staat, Grossraum, Nomos: Arbeiten aus den Jahren 1916-1969 (1995), which includes the following relevant studies: Raum und Grossraum im Volkerrecht, 234-268, Volkerrechtliche Grossraumordnung, 269-320; Die Raumrevolution: durch den totalen Krieg zu einem totalen Frieden Die letzte globale Linie, 441-48. See also Carl Schmitt, Grossraum gegen Universalismus. Der Völkerrechtliche Kampf um die Monroedoktrin, 6 Zeitschrift der Akademie für Deutsches Recht (1939), 333; Mathias Schmoeckel, Die Grossraumtheorie (1994); Oliver Eberl, Großraum und Imperium. Die Entwicklung der "Völkerrechtlichen Großraumordnung," aus dem Geiste des totalen Krieges, in: Rüdiger Voigt (ed.) Großraum-Denken. Carl Schmitts Kategorie der Großraumordnung (2008), 185-206; Horst Dreier, Wirtschaftsraum-Großraum-Lebensraum. Facetten eines belasteten Begriffs", in: Horst Dreier, Hans Forkel \& Klaus Laubenthal (eds.) Festschrift 60 Jahre Würzburger Juristenfakultät (2002), 66-73. For English language studies of Schmittian Grossraum theory, see Carl Schmitt, The Großraum Order of 
works continue to attract considerable controversy, ${ }^{8}$ and have generated debates in the fields of geography as well as international relations. ${ }^{9}$ However, the present study seeks to move the contemporary debate forward in a more empirical, less jurisprudential, direction. It applies and critically "tests out" this Grossraum model, which, as a supposedly "generally applicable" theoretical conception, is arguably rather generic and, in certain material respects, indeterminate, concerning the implications of concrete developments currently taking place with a key region of central Asia: namely, the emergence of the SCO. ${ }^{10}$ As a result, we need to cross-reference this conceptual model with the implications of a real and emerging regional body, interpreting each in terms of the other.

\section{The Idea of Grossraum as a possible ground for a regionalist theory of international law ${ }^{11}$}

3. The term Grossraum, which was first used in an economic context to refer to, for example, transnational energy provisions, now has to be extended into the spheres of international law and relations. The idea of Grossraum refers literally to a large/ greater space exceeding that of a formal state border. It is linguistically akin to the

International Law, in: Carl Schmitt: Writings on War (2011), 75-124; Peter Stirk, Carl Schmitt's Völkerrechtliche Grossraumordnung, 20 History of Political Thought (1999), 357-374; Chantal Mouffe, Schmitt's Vision of a Multipolar World Order, in: William Rasch (ed.) Special Issue on Schmitt's Nomos of the Earth, 104 South Atlantic Quarterly (2005);; Michael Salter, Law, Power and International Politics with Special Reference to East Asia: Carl Schmitt's Grossraum Analysis, 11 Chinese JIL (2012), 393-427; Martti Koskenniemi, Letter in Response to Michael Salter's Recent Paper on Carl Schmitt's Grossraum, 12 Chinese JIL (2013), 201-202. Michael Salter, A Reply to Koskenniemi’s Letter, 12 Chinese JIL (2013), 203-210.

8 For a recent interesting, if reductionist, critique claiming that Schmitt's historical narrative is flawed and his distinctions are prejudicial, see Benno Gerhard Teschke, Fatal attraction: a critique of Carl Schmitt's international political and legal theory, 3(2) International Theory (2011), 179-227; Gopal Balakrishnan, The Geopolitics of Separation: Response to Teschke's "Decisions and Indecisions", 68 New Left Review (2011), 57-72; Benno Teschke, The Fetish of Geopolitics: Reply to Gopal Balakrishnan, 69 New Left Review, 81-100.

9 David Chandler, The revival of Carl Schmitt in International Relations: The last refuge of critical theorists? 37 Millennium (2008), 27-48.

10 Carl Schmitt, Nomos of the Earth, 2003, 278.

11 Issues of regionalism were debated during the International Law Commission (ILC) report on fragmentation of international law: Fragmentation of International Law: difficulties arising from the diversification and expansion of International Law. Finalized by Martti Koskenniemi. The Erik Castrén Institute Research Reports (2007). 
distinction between the "City of London" and "Greater London" as the metropolitan Grossraum of this city extending well into the suburbs. ${ }^{12}$ As Elden notes:

The term has a sense of a "sphere of influence," and "geopolitical space" may be closer to the meaning. By the term Schmitt intends to grasp an area or region that goes beyond a single state (that is, a specific territory), to comprehend much larger scale spatial orderings, complexes or arrangements. ${ }^{13}$

4. A Grossraum involves a geographically specified regional sphere of special interest and qualified sovereignty identified in terms of global spatial thinking. Such thinking recognises the division of the planet's land, maritime and airspace into different regions characterised by distinctive cultural traditions and orientations in core political ideas, such as communitarian/family-centred Asian values as opposed to the ideology of Western liberal atomistic individualism.

5. The Schmittian idea of Grossraum also embodies a distinct-if polemically defined-" political idea" with which the other member States broadly identify, and which they accept as generally legitimate on the basis of their overlapping cultural traditions and aspirations, e.g., principles of "liberal democracy," "social democracy," "Communism," etc. ${ }^{14}$ Core Grossraum principles include a prohibition of foreign

12 On the underdeveloped nature of analysis to date, see Ruslan Maksutov, The Shanghai Cooperation Organization: A Central Asian Perspective, SIPRI project paper (2006) (www.sipri.org/files/PP/SIPRIPP17.pdf. For an early English discussion of Carl Schmitt's Grossraum concept from a leftist perspective, see Garry L. Ulmen, American Imperialism and International Law_Carl Schmitt on the US in World Affairs, 72 Telos (1987), 43-71; Joseph W. Bendersky, Carl Schmitt (1983), 251; Elden, above n.2; Gopal Balakrishnan, The Enemy. An Intellectual Portrait of Carl Schmitt (2000), $226 \mathrm{ff}$.

13 Elden, above n.2, 19.

14 Each Grossraum is shaped by "the leading powers, whose political idea radiates through a specific Grossraum and who specifically exclude the intervention of alien powers into this Grossraum". Carl Schmitt, Grossraum versus Universalism: The international legal struggle over the Monroe Doctrine, [1939] in Stephen Legg (ed.) Spatiality, Sovereignty and Carl Schmitt: Geographies of the Nomos (2011), 101. For a full German language study of Grossraum theory, see Felix Blindow, Carl Schmitts Reichsgrundung: Strategie fur einen europaischen Grossraum (1999). The relevance of Schmitt's Grossaum theory is addressed more fully in the German-language literature. Drawing upon sources restricted arbitrarily to Schmitt's pre-war writings, Alexander Proelß, addressed connections between this theory of Großraum and the modern EU concluding controversially that the differences were more significant than the similarities in that the latter remains too diverse, decentralised, and market-oriented policies to be understood as a Grossraum. See Alexander Proelß, Nationalsozialistische Baupläne für das europäische Haus? John Laughland's "The Tainted Source" vor dem Hintergrund der Großraumtheorie Carl Schmitts, in: 12 Forum Historiae Juris (2003). For a useful introduction, see Jean-Francois Kervegan, Carl Schmitt 
extra-regional intervention as part of a wider commitment to an anti-imperialist type of defensive orientation and response to would-be global hegemons, such as the US or the former Soviet Empire. In brief, a Grossraum type regional entity is territorially-bounded geographically and, in opposition to the pseudo-universalism of liberal cosmopolitan and Marxist-Leninist ideologies, particularistic in its distinctive ideology and core political ideas. $^{15}$

6. This entity occupies an intermediary zone between the national and universal levels of legal regulation. Its elucidation by scholars allows us to largely jettison the traditional nation state-centric model as the central focus for international law analysis; while still preserving a concrete territorial and spatial orientation. Within the context of late modernity, the latter is vital. It stands as a necessary corrective to the universalistic dictats of "one world" liberal cosmopolitan approaches to international law and relations. In such approaches, the UN Security Council is interpreted as an emerging federal world government in which entire continents, such as Africa, lack democratic representation within the highest decision-making circles; while Western states are grossly overrepresented in an institution that presumes to legislate in the name of "humanity".

7. By contrast, Grossraum analysis projects the possibility of a wider pluralistic interGrossraum global order that aims to preserve a small number of separate, sovereign regional entities, each with their own territorial zone of influence free of extra-regional interference. Every Grossraum operates under the accepted leadership of a major regional protectorate/superpower entity, equipped with region-wide form of qualified sovereignty, and which is held responsible for pan-regional security and development more generally (i.e., the "leading power".) ${ }^{16}$

8. Grossraum analysis claims to be more realistic and attuned to contemporary realities than more traditional approaches to international law and relations. It attempts to adapt the increasingly artificial and anachronistic state-centred interpretative framework of traditional international law. Adaptation is need to better account for the realities on-going transformations of international relations dominated by technical, industrial, and economic developments in transnational forms of regional governance.

and "World Unity", in: Chantal Mouffe (ed.) The Challenge of Carl Schmitt (1999), $54-73$.

15 On fake universalism, see Gary Ulmen, Pluralism contra universalism, 31(5) Society (1994), 32-36.

16 The terminology here is important. Under classic Grossraum theory, the leading power was termed a "Reich," which suggests a state-like body, and this has often been translated as "leading state". The wider term that we consider more appropriate to contemporary applications is "leading power," which could accommodate a higher-level regional executive authority, akin to the EU Commission and Council, responsible for some aspects of governance and administration. Carr once suggested that immediate post-war Britain could - if it only shed the spatially incoherent British Commonwealth-play the role of the "leading power" of a Western European Grossraum. Carr, above n.1, 73-74. 
It recognises how these developments have tended to erode the absolute status afforded by traditional approaches to the territorial state and associated doctrines of purely national sovereignty (even for the Vatican). Grossraum analysis recognises how international law scholarship has to take seriously how particular and regionally demarcated spatial spheres have increasingly become the de facto conceptual basis for such law in its inevitable interaction with the historically changing geopolitics of international relations.

9. In defiance of the artificial distortions and abstractions created by traditional formalistic doctrine of the "equality of all states," the Grossraum model correctly registers the reality and future implications of the existence of different levels and quotas of geopolitical power and influence. In turn, what has followed from the erosion of the traditional statist model of international law is that our discipline's traditional "flattened out" and purely horizontal model, which places every entity recognised as "a sovereign state" on a par with every other, has become anachronistic. This traditional model now needs to be supplemented with a spatial framework whose realisation is evidenced by its recognition of a vertical dimension of stratification. The United States and, as an emerging superpower, China whose zones of influence transcend their national borders, are not "states" in the same sense that the Vatican or Monaco are "states". For this reason, Grossraum theory seeks to wake us up from the dream world of abstractions engendered by the traditional "equality of states" doctrine, incapable of recognising the significance and implications of such "extra-territorial" zones of influence as spaces of sovereign power irreducible to a single state. It does so by recognising the eminence of a "leading power" as a regional superpower co-constituting the order of that space. ${ }^{17}$

10. Such recognition of the importance of vertical stratification is not purely theoretical or doctrinal. It does not merely aim to add a qualifying sentence or two to standard works on international law with respect to the formalistic "equality of states" doctrine. Instead, it is concerned with international law in action, as a living regulatory force engaged with concrete regulatory tasks within the context of shifting patterns of international relations. Whatever validity we can claim for a Schmittian Grossraum model stems from its status as a historically constructed, concrete and politically contemporary conception that is no longer grounded in the evaporating $19^{\text {th }}$ century legacy of the traditional nation state. Its claims to relevance come from an empirical analysis of the technical, industrial and economic spheres that have increasingly enhanced levels of actual and potential regional integration and inter-regional contacts.

11. How then does Grossraum analysis differ from more traditional state-centric approaches? Such analysis promotes recognition of tendencies towards an emerging multipolar international order, centered around a small number of different powercentres. Here, the theory and practice of international law would have to finally

17 Michael Salter, The Return of Politicised Space: Carl Schmitt's Re-Orientation of Transnational Law Scholarship, 17(1) Tilberg Law Review (2012), 5-31. 
recognise how, to an increasing extent, it is a small number of regional power blocs exercising sovereign power within transnational spaces that have become the decisive players within transnational relations more generally, with the EU as, perhaps, the most striking example to date. Yet the tendency to consider the EU through the traditional lens of a federalism versus nation-state dichotomy, as if the EU signalled no more than a recycling of European political-constitutional categories, misses out on the wider global implications of the development of a European Grossraum. In pursuit of an expressly multi-polar agenda, international law scholarship would then have to strive to adapt and modify its traditional State-centric categories. These categories need to be reconfigured to accommodate the implications of growing empirical developments towards regionalism at a number of different levels within a vertically differentiated model of how law operates within the context of, and as a factor within, the geopolitics of international relations.

12. For example, the traditional and overly formalistic notion of "territory" would need to be redefined in a far more realistic direction. The primary spatial category appropriate to a Grossraum involves an extended spatial realm of influence and hegemonic control comprised of two or more adjacent nation states, and about which it is possible to identify widely recognised and specific quasi-jurisdictional borders differentiating a strictly relative "inside" from an "outside". Arguably, the ill-fated Locarno Treaties negotiated by the democratic Weimar Republic, Britain, France and others on 5-16 October 1925 had elements of a potential Grossraum. They spatially divided the borders in Europe into two distinct categories: western, guaranteed by the Locarno treaties, and a second zone made up of Germany's eastern borders with Poland, which were then accepted as open for revision by peaceful means. Assuming the role of leading hegemonic power, British Prime Minister Austen Chamberlain then announced publicly that Britain's defensive frontier was no longer the English Channel but on the Rhine. In effect, these Treaties sought to spatially reconstitute Western Europe as a British co-protectorate. ${ }^{18}$ Given Britain's empirical status as major world power within an extensive empire at this time, such a notion, which of course radically contradicts the traditional "equality of states" doctrine, was entirely realistic. (Of course, scholarly recognition of the nature and implications of realities, whether in the field of medicine or international relations, does not amount to their normative endorsement.)

13. In short, the conception of Grossraum suggested here remains a concrete, historical and politically contemporary idea: one that is specific to a unique constellation of transnational relations. It is closer to a singular historical event than a formal and abstract "legal" concept. This conception refers to the idea of a spatially-demarcated and internally integrated regional space, made up of a voluntarily created association of individual

18 See 54 League of Nations Treaty Series, 290-301; Patrick O'Cohrs, The First "Real" Peace Settlements after the First World War: Britain, the United States and the Accords of London and Locarno, 1923-1925, 12(1) Contemporary European History (2003), 1-31; Jonathan Wright, Locarno: a democratic peace? 36(2) Review of International Studies (2010), 391-411. 
states, and operating within defined borders with overall regional security guaranteed by a "leading power". A Grossraum is integrated by adherence to a common political idea or ideas; and its core principles include a prohibition of foreign extra-regional intervention as part of a wider commitment to an anti-imperialist defensive orientation that harmonises with the prospect of a pluralistic, multipolar international ordering accomplished and sustained in part through law; that is, a new model of an inter-Grossraum order. The idea of Grossraum thus also refers to a zone given form by a hegemonic political command carrying a leading power's organising principle that is able to animate a concrete political and constitutional order governing a vertically arranged plurality of national institutions at its interior. Contrary to the covert depoliticisation of liberal cosmopolitanism, Grossraum analysis openly recognises regional reterritorialisation of transnational politics as central to any realistic form of international law scholarship analysis, and-with it - the open affirmation of the logics of achieving political unity through different forms of regional integration conceived of as an on-going historical process and ideological performance.

14. It would, however, be self-contradictory and contextually inappropriate for us to mechanically transpose the Grossraum model in its entirety, which largely originated in the USA's 1823 Monroe Doctrine, to other contexts, such as contemporary central Asia. This is because the substantive content of the core structures are historically specific innovations and "events," even though the structuring principles themselves are potentially applicable. ${ }^{19}$ Historical truths cannot be true more than once.

15. Our study provides a close interpretation of those empirical and institutional details of the unfolding SCO project that either confirm or-just as importantchallenge the defining characteristics of a pluralistic Grossraum model of regionalism as previously renovated and salvaged from Schmitt's writings. A selective reconstruction is needed to free it from any trace of those problematic features stemming from the immediate historical-ideological context of its original formulation between 1939-42 within Nazi Germany and its author's short-lived - but morally deplorablecomplicities with this regime. ${ }^{20}$ Can the cross-referencing of an empirical analysis of the SCO cast new light upon the implications and limits of Grossraum theory, and vice versa? This is our gamble, and arguably the stakes are considerable.

19 Schmitt, above n.7, 83-84.

20 For a discussion on the need to salvage the viable aspects and rational core of Schmittian theoretical writings on law from the contingent hubris that bears the traces of its contextual emergence within Nazi Germany, see Michael Salter, Carl Schmitt: Law as Politics, Ideology and Strategic Myth (2012), chapter two. There are analogies here with salvaging aspects of Marxist writings on law written under Soviet censorship from their authors' indirect complicities with genocidal forms of Stalinism. To be fair, Schmitt continued to develop his Grossraum concept long after the collapse of Nazism and in ways that are clearly detached from and irreducible to this racist ideology and movement. For criticisms of aspects of Schmitt's specifically regionalist approach to international law, see Salter above n.7. 


\section{Linking Grossraum theory to China as a "leading power"21}

16. How do classical forms of Grossraum theory relate to the position of China, and from there to the role of this emerging regional superpower within Central Asia? This linking subsection connects theoretical writings on Grossraum theory presented above, with the empirical details of the SCO addressed by the remainder of our study.

17. In 1978, Schmitt recognised the potential of China to challenge the two other industrially developed Grossräume, the US and the Soviet Union, whose "internal" political bottlenecks were overcome in the same way as in a federal state or in a confederation of states. Of course, at this time Schmitt's contention was highly speculative. China's evolution had not yet fulfilled its potential to become capable of regularly preventing political interventions by extra-regional powers in its broader greater space. ${ }^{22}$ According to Schmitt in 1978, what is crucial is for modern China to contribute increasing towards: "a set of Grossräume that are rationally balanced both within and among one another". 23 Apart from Schmitt, others too have noted how China has proactively promoted the $\mathrm{SCO}$ as a regionalist response to the threat of unipolarity presented by the collapse in 1989-90 of the bipolar nature of the Cold War. ${ }^{24}$

18. Clearly, China of today has succeeded in massive economic and social development over the past 30 years. For us, the resulting question is whether it now has to be recognised as having, to some extent at least, graduated to the status of a joint "leading power" of a central Asian Grossraum: one whose sovereign zone of influence is partly embodied in the SCO, and which is capable of resisting the over-generalisation of supposedly universally applicable American ideas, beliefs and ideologies? Can the SCO, particularly when understood in Grossraum terms, fulfil the imperative of Grossraum theory by providing a vital counterweight that demonstrates that earth will always be bigger than a zone controlled de facto by the USA and its international proxies and controlled states, including NATO subscribers?

19. In what follows, we will concentrate on unfolding those empirical elements of the SCO, including China's role as a "leading power," that are especially relevant to the question of its possible characterisation as a Grossraum in the revised sense addressed above. This is important because many extra-territorial aspects of the SCO simply

21 For scholarly analysis of the SCO, see Enrico Fels, Assessing Eurasia's Powerhouse. An Inquiry into the Nature of the Shanghai Cooperation Organisation, (2009).

22 Carl Schmitt, The legal World Revolution, 72 Telos (1987), 80-81.

23 Carl Schmitt, Theory of the Partisan (2007), 58-59.

24 Yi Wang argues: "Apart from increasing participation in existing organizations and forums, China's new-found activism also emerged in the building of its own regional architecture in response to the new strategic environment characterized by the unipolar setup of the post-Cold War order. An important case in point was the establishment of the Shanghai Cooperation Organisation (SCO)". Yi Wang, Australia-China Relations Post 1949: Sixty Years of Trade and Politics, (2012), 167. 
cannot be grasped in traditional state-centric terms. ${ }^{25}$ The remainder of this study will address the SCO's emergence and internal governance; its cultural underpinning and the related issue of the existence of a unifying "political idea". The remaining discussion addresses the SCO's military-security integration, Economic integration, the identity and status of its "leading powers," the SCO's foreign policies and efforts to achieve a security and geo-political equilibrium. Once again, the ultimate aim is analytical not purely descriptive: to provide an empirical basis for evaluating the extent to which the SCO can be usefully understood as a revised and emerging type of regional body that can be usefully interpreted in Grossraum terms. In other words, the remainder of our study takes forward the question of the SCO's significance insofar as its empirical details and structure both partly exemplify-but also substantially challenge- the framework of classical Grossraum analysis. ${ }^{26}$

20. There is a surprising lack of scholarship on the specifically regionalist dimension of the SCO understood as an extended spatial zone of influence and organisation, or "Grossraum”. Cheng Gao's article states that the theory of Grossraum order is one of the original theories of regionalism. ${ }^{27}$ However, he does not further discuss the relationship between the Grossraum model and the SCO as an example of this type regional body. ${ }^{28}$ Scholars in China have yet to undertake significant academic research into the effect the SCO has exerted or could exert upon international law regulatory practices generally, and with respect to questions over regionalist dimensions of such law in particular. This is a deficit that the following subsections aim to redress.

\section{The Emergence of the SCO}

21. The SCO is a: "permanent intergovernmental international organisation" whose creation was proclaimed on 15 June 2001 in Shanghai, China. ${ }^{29}$ The SCO emerged as the successor to the ad hoc arrangement of the "Shanghai Five," which had been used as a temporary device by Russia, China, Kazakhstan, Kyrgyzstan, and Tajikistan

25 Boland, above n.6, 7 (e.g., paper tiger vs. military alliance).

26 Methodologically our initially sympathetic reconstruction of Schmittian Grossraum theory contributes to an "immanent critique" in which the contradictions emerge and become thematic towards the end of the analysis.

27 Cheng Gao, Historical Experience and Study on the Order of East Asia: International Relations of China in Perspective of Innovative Theory, (in Mandarin) 3 Foreign Affairs Review (2013).

28 He suggests in this article that the traditional regionalism, or the ways used by western scholars to research Eastern Asia, is somewhat limited. He therefore states that research on the international relationship between China and Eastern Asia should be conducted in the specific context of the history of China. This means that "the tributary system," which existed in the Qing dynasty, and which is now representative of modern-day Eastern Asia, should be properly recognised.

(www.sectsco.org/EN123/brief.asp). 
from 1996 to 2001 as a forum for addressing Sino-Soviet border disputes and demilitarising borders. ${ }^{30}$ In 2001, and in an effort to create a more permanent and institutionalised arrangement with some common features with other longer-standing regional bodies, it transformed itself into the SCO. This was declared to be an essentially voluntary and treaty-based project of "indefinite duration," which each member has ratified (art. 21 of the SCO Charter). ${ }^{31}$

22. The first summit of Heads of State was organised in 2001, but the organisation has developed rapidly since then. ${ }^{32}$ On 15 June 2001, Uzbekistan was the first non-founding member to be admitted. Currently, there are the following SCO "Observer States:" India, ${ }^{33}$ Iran, ${ }^{34}$ Mongolia, ${ }^{35}$ Pakistan ${ }^{36}$ and-from mid-2012Afghanistan; ${ }^{37}$ whilst the SCO's "Dialogue Partners" comprise Belarus, Sri Lanka and-since June 2012-Turkey. ${ }^{38}$ Guest attendances at SCO annual meetings

30 Mutlaq Al-Qahtani, The Shanghai Cooperation Organization and the law of international organizations, 5 Chinese JIL (2006), 130-131.

31 Maksutov, above n.12 1, 3-5; Al-Qahtani, above n.30, 330-331.

32 Cooley, above n.3, 79; Al-Qahtani, above n.30, 330-331.

33 India has recently pressed for full SCO membership: India Keen to Become Member of SCO, The Times of India, 1 June 2010 (http://timesofindia.indiatimes.com/ india/India-keen-to-become-member-of-SCO/articleshow/5995619.cms). Russia has supported India and Pakistan's admission as fill members, and in 2014 at the Dushanbe summit China has begun to support this. India and Pakistan could be elevated from observer to member status as early as 2015, while other observer states and Dialogue Partners like Belarus, Mongolia and Turkey are expected to be provided with more opportunities to participate in SCO activities. See Richard Weitz, The Shanghai Cooperation Organization (SCO): Rebirth and Regeneration?, 10 October 2014, (www.isn.ethz.ch/Digital-Library/Articles/Detail/?ots591=4888caa0-b3db-146198b9-e20e7b9c13d4\&lng=en\&id=184270).

34 On the possible future expansion of the SCO in to the Persian Gulf region if and when Iran becomes a full member, see Matthew Brummer, The Shanghai Cooperation Organisation and Iran: A Power-full Union, 62(2) Journal of International Affairs (2007), 185.

35 Mongolia and SCO Boost Cooperation, MONTSAME State News Agency report, 24 January (2010). 7.

36 Cheng Guangjin and Yang Xue, SCO Appraises Membership of Iran, Pakistan, China Daily, 4 February 2010 (www.chinadaily.com.cn/world/2010-02/04/ content_9425076.htm); SCO Summit: Pakistan Eyes Full Member Status Voice of Karachi, 25 November 2010 (http://voiceofkarachi.blogspot.com/2010/11/ sco-summit-pakistan-eyes-full-member.html).

37 See also SCO accepts Afghanistan as observer, Turkey dialogue partner, Xinhua News Agency (2012) (http://news.xinhuanet.com/english/china/2012-06/07/c_ 131637206.htm). The Regulations on the SCO Observer Status at the 2004 Tashkent Summit enhanced the process of cooperation with non-member states.

38 SCO website, Regulations on the Status of Dialogue Partners of the Shanghai Cooperation Organisation, 28 Aug 2008, (www.sectsco.org/EN/show.asp?id=64). 
include ASEAN, CIS and Turkmenistan. There are recent indications that India and Pakistan could become the next full members. ${ }^{39}$

23. Taken together, the full SCO member states now occupy a territory of over 30 million square kilometers, which makes up around $60 \%$ of the Eurasian continent, half of the world's landmass with a population of 1.5 billion comprising more than a quarter of the planet's population. ${ }^{40}$ If Mongolia finally graduates from observer status to full SCO membership, then there will be a solid and highly defensible landmass of SCO member states - akin to the USA — with no "internal gaps" as it were for rival power blocs, such as NATO, to exploit or infiltrate.

24. In 2010, Beijing sought to institutionalize the rules and principles for admitting new SCO members or elevating the "observer status" of Mongolia, Iran, India and Pakistan. This included a clause that applicants ought not be subject to UN sanctions, a clear indication that Iran would be at least temporarily excluded from membership, ${ }^{41}$ although it has pressed for inclusion. ${ }^{42}$

25. A Grossraum differs from a traditional empire, such as that of $18^{\text {th }}$ and $19^{\text {th }}$ century Britain, in the sense of being a voluntary, treaty-based organisation with a guaranteed right to withdraw, understood as an expression of qualified yet unextinguished national sovereignty. Arguable, this question of the internal constitutional public law arrangement is vital to the SCO and any other Grossräume because the latter presupposes a truly voluntary (if not always harmonious) constitutional "union".

26. In turn, this factor presumes that any member state can reverse its original sovereign decision to join the SCO; and thereby return to its former formally "independent" position as a traditional nation sovereign state. However, in practice and in common with the EU, the decision to join and integrate may be easier to achieve than for a member state to later disentangle itself from a thread of relations, including specific obligations, which have arisen as a consequence of SCO membership. Art 13 of the SCO's Charter recognises a right to withdraw providing states comply with certain

39 (http://zeenews.india.com/news/nation/sco-summit-may-allow-india-pakistanto-become-regular-members_1465617.html).

40 The SCO members and observers account for nearly 3 billion people, over $40 \%$ of the world population: 2005 World Population Data Sheet, (www.prb.org); (www. nationmaster.com/red/graph/mil_arm_for_per-military-armed-forces-personnel \&b_printable=1). The SCO covers an area of 30.2 million square $\mathrm{km}$, with a combined population of 1.53 billion (http://english.peopledaily.com.cn/n/2014/ 0618/c90785-8743206.html). Full SCO states' territory occupies 60\% of Eurasia. See Ryabinin Yevgeny, Integration processes on Eurasian territory, Eurasia Centre (www.viaevrasia.com/en/integration-processes-on-eurasian-territory-ryabininyevgeny.html).

41 Cooley, above n.3, 78.

42 See Iran's SCO Membership to be Beneficial, presstv.ir, 24 November 2010 (www. presstv.ir/detail/152492.html). 
formalities, including an official notification, a 12 month delay and completion of all pre-existing obligations. ${ }^{43}$

\section{IV.A. Internal governance}

27. Any viable Grossraum requires adherence to widely acceptable principles of internal governance or "constitutionality", even where this is not immediately beneficial to a member state's national interests. One challenge and task facing every Grossraum is how to best organise its leading and subordinate institutions so that they exhibit a measure of coherence and internal constitutionality, as well as sufficient administrative-public law rationality to both formulate and effectively apply policy decisions. Such principles will be contextually specific. Indeed, Grossraum analysis cannot be founded on a type of universalistic "human rights" agenda whose liberal cosmopolitanism is resolutely non-historical and anti-pluralistic in its approach. On the other hand, Grossraum analysis also recognises that modernity has generated a legally significant and secularised conception of the "self-determination of peoples". This principle cannot be ignored, even by an expressly and militantly regionalist approach. It follows that "rights to self-determination" of distinct peoples need to be accommodated, not in terms of universalistic and ahistorical entitlements, but rather as historically constructed expectations associated with the projects of achieving a contextually appropriate forms of democratisation and constitutional governance more generally. In particular, this collective quasi-right (i.e., widely felt entitlement) is not fixed as to its content. This is because peoples can be expected to demand different results from the process of selfdetermination and to give them different degrees of priority.

28. In addition, the felt need for democratic self-determination is likely to vary markedly from one context of application to another, and perhaps have a greater priority in more economically developed situations than in contexts where basic material needs to clean air, water, food, personal security, housing, and health provisions are only barely satisfied. Accordingly, it may prove to be the case, that if and when SCO regional policies on public interest /welfare provisions, and economic development more generally, succeed in raising living standards in poorer areas, then political demands for self-determination of all peoples within this Grossraum may well move up the political agenda. It is here that the pluralistic approach of Grossraum analysis demonstrates its greater coherence, flexibility and pluralistic sensitivity to- and accommodation of-regional differences compared with the imperial unilateralism and assimilation orientation of pseudo-universalistic liberal ideologies of "human rights". This approach provides a sharp contrast to the universalistic orientation covertly

43 "Any member State shall be entitled to withdraw from SCO by transmitting to the Depositary an official notification of its withdrawal from this Charter no later than twelve months before the date of withdrawal. The obligations arising from participation in this Charter and other instruments adopted within the framework of SCO shall be binding for the corresponding States until they are completely fulfilled". 
rooted in spatially alien Western values that are superimposed and insisted upon in a fundamentalist manner by advocates of liberal cosmopolitanism.

29. The SCO's public emphasis upon multilateralism and the goals of regional harmony provide key themes for its legitimation both internally and externally. This means that it has rejected an executive format comprising a bureaucratic and technocratic administrative apparatus akin to the EU's European Commission and Council authorised to make decisions directly applicable to member states. Instead, the SCO relies upon intergovernmental ties governed by a principle of consensual decisionmaking. Chinese officials view this procedure as critical to building the trust and "regional harmony," itself perceived to be a precondition for promoting closer regional integration. However, arguably the SCO's thinly staffed and poorly financed institutions still lack sufficient executive powers to effectively tackle many regional issues, problems and disputes, such as the sensitive water management issue. ${ }^{44}$

30. The following organisational chart captures the SCO's formal institutional structure.

In brief, the Heads of State Council (HSC) is the SCO's highest decision-making body and meets only annually to issue "decisions". 45 Below this in seniority is a Heads of Government Council (HGC) which also meets annually in SCO Summits to discuss: "a strategy for multilateral cooperation and priority directions within the Organisation's framework, to solve some important and pressing issues of cooperation in economic and other areas as well as to adopt the Organisation's annual budget". 46

31. Expressing the SCO's essentially intergovernmental character, ${ }^{47}$ the highest executive organ is the Committee of Ministers, consisting of foreign ministers. This body has the power to conclude agreements and conventions, and to develop a common policy to be followed by each government on a range of issues. The SCO's consultative body is the Parliamentary Assembly, which consists of representatives of the member states' legislative bodies, and has the power to make recommendations to the Committee. The most important issues within the Committee are decided by unanimity of members casting a vote and a majority of members entitled to sit on the Committee. ${ }^{48}$ This is a double condition because other non-members-special guests or observers-may have representatives on the Committee. Other issues require either a simple majority, or a two-thirds majority of the representatives entitled to sit on the Committee.

Cooley, above n.3, 78 .

45 The current Council of Heads of State consists of: Almazbek Atambayev (Kyrgyzstan); Xi Jinping (China); Islam Karimov (Uzbekistan); Nursultan Nazarbayev (Kazakhstan); Vladimir Putin (Russia); Emomalii Rahmon (Tajikistan).

46 (www.sectsco.org/EN123/brief.asp).

47 Mikhial Troitskiy, A Russian Perspective on the Shanghai Cooperation Organisation, in: Alyson J. K. Bailes, et al, SIPRI Policy Paper No. 17 (2007), 44 (http://books. sipri.org/product_info?c_product_id=338).

Under Art. 20a. 
THE STRUCTURE OF THE SHANGHAI COOPERATION ORGANISATION

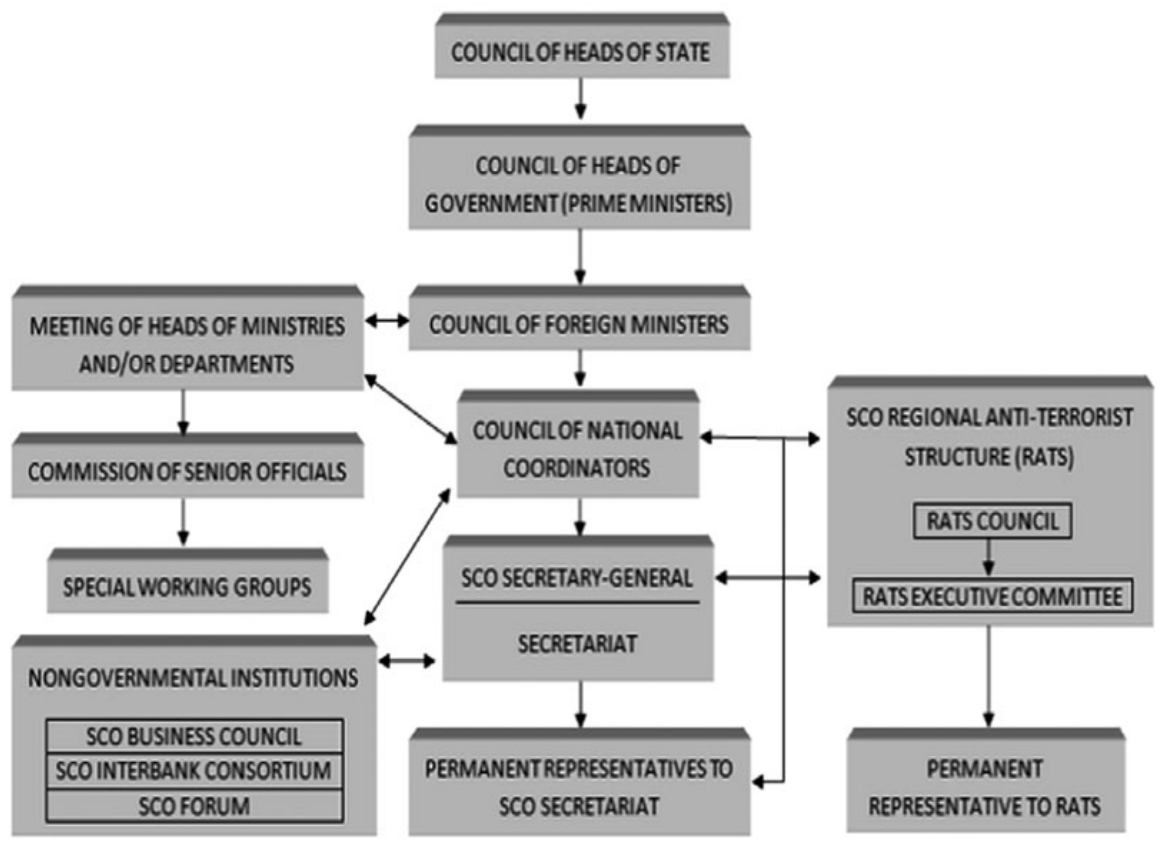

32. Compared to the Committee, the decision-making within the SCO Heads of State Council seems more democratic due to the consensus rule, which approaches unanimity. ${ }^{49}$ This is, perhaps, the only expressly democratic element of the SCO in its evolution to date, a point which had attracted some criticism in terms of a lack of dispute resolution mechanisms akin to the European Court of Justice. ${ }^{50}$ On the other hand, the SCO has organised election monitors from 2005 in Central Asian states, which is surely relevant to countering claims that the culture of the SCO is somehow essentially anti-democratic. $^{51}$

33. In addition, there are also mechanisms for holding meetings at the level of Speakers of Parliament, Secretaries of Security Councils, and Foreign Ministers. ${ }^{52}$ This also applies to meetings between Ministers of Defence, Emergency Relief, Economy, Transportation, Culture, Education, and Healthcare. Other forums are concerned with SCO legal cooperation between Heads of Law Enforcement Agencies, Supreme Courts and Courts of Arbitration, and Prosecutors General. ${ }^{53}$ A Council of National Coordinators

49 Boland, above n.6, 8.

50 Al-Qahtani, above n.30, 139.

51 Boland, above n.6, 16.

52 This council hold regular meetings to discuss the current international situation and the SCO's interaction with other international organisations.

53 (www.sectsco.org/EN123/brief.asp). 
of SCO Member States (CNC) is responsible for coordinating multilateral cooperation and interactions within the SCO Charter framework. The CNC possesses two permanent bodies-the Secretariat based in Beijing (since $2004^{54}$ and a Regional CounterTerrorism Structure in Tashkent, Russia (discussed in more detail below).

34. The Secretariat is the SCO's primary executive body serving to implement organisational decisions and decrees, draft proposed documents including declarations and agendas, as well as operating as a document depository. It is also responsible for arranging specific activities within the SCO framework, and promoting and disseminating official information about the SCO. The important posts of the SCO SecretaryGeneral and RCTS Executive Committee Director are appointed by the HSC for a period of three years, and, from 01 January 2013, these posts are held by representatives of the SCO's two “leading powers" Dmitry F. Mezentsev (Russia) and Zhang Xinfeng (China) respectively. ${ }^{55}$

35. Whilst recogising the considerable progress the SCO has achieved in little more than a decade, it is arguable that there is still a long way to go before it can fully develop and refine its institutional structure. Joobani recently argued for the following necessary additions: "Creating impartial administrative staff, engaging civil society arrangements, appointing apolitical technocrats ... establishing a judicial body for settlement of internal disputes among the member states ... and delineating the exact boundaries between terrorism and secessionism ... are among a wide variety of proposed challenges that should be dealt with if the SCO wants to survive". 56

36. A further constitutional issue relates to the governance of peoples lacking their own nation states. Any viable Grossraum and Grossräume order has to accommodate the presence of diverse peoples with divergent ethnicities, religions, subcultures and cultural / national identities. Such diversity always has the potential to become politicised on an "us vs. them" / "friend vs. enemy" basis and thereby operate a source of sectarian conflict, even violent and terroristic "separatism". On the other hand, SCO-wide projects have the capacity to generate favourable public interest in this regional body as a source of welcome material services, including enhanced health care and education, ${ }^{57}$ and the provision of food supplies to cover potential emergency

54 SCO Secretariat Launched in Beijing, People's Daily Online, 15 Jan 2004 (http:// english.peopledaily.com.cn/200401/15/eng20040115_132679.shtml); (www.china. org.cn/english/international/84870.htm).

55 (www.sectsco.org/EN123/brief.asp).

56 Hossein Aghaie Joobani, The Shanghai Cooperation Organization in Light of Organization Theory, Electronic International Relations, Feb 222013 (www.e-ir.info/2013/ 02/22/the-shanghai-cooperation-organization-in-light-of-organization-theory/).

57 SCO Business Council website, SCO "Health-Care Party" Left Tajikistan, 17 September 2008 (http://bc-sco.org/?level=10\&id=538\&lng=en). 
situations. ${ }^{58}$ In turn, such activities probably contribute towards further SCO-wide legitimacy among beneficiaries - and hence greater solidarities and integration - at the cultural level, which includes elements of "soft power". ${ }^{99}$ As with the EU, the citizens of the SCO States are not directly involved either as individuals or through delegates in the workings of this organisation, which - in this sense-remains firmly intergovernmental. ${ }^{60}$ As "subjects" of regional governance, the SCO does not legislate "for them" as it were, as with the EU. Rather, decisions are taken between the leaders of the member States, which are then further implemented internally. Hence, the idea of SCO citizenship remains embryonic This can be contrasted with the EU whose Parliament and Commission legislate in the form of regulations, directives, decisions, recommendations and opinions. The SCO model is based on mutual benefits on the state level, whereas the EU provides for quasi-constitutional guarantees to the member states' populations, such as the individual access to the EU specific Courts, which more closely resemble citizenship entitlements.

37. Although the formal statements of the SCO refer to existing historical ties between the peoples of the member states, it has yet to develop a mechanism for integrating these peoples, or for recognising their share of "popular sovereignty" outside an inter-governmental framework. Instead, the task of integrating minorities and balancing minority and majority concerns in particular policy fields is left to individual member states, with no overarching SCO mandate on this topic to date. Here, we need to recall that ethnic Chinese and Russians are effectively "minority groups" within the Central Asian members of the SCO, and therefore potentially in need of regional protection from intolerant, xenophobic or resentment-driven majority populations in those states that traditionally have lacked a pluralistic political culture. ${ }^{61}$ The predominant way in which "peoples" are addressed by the SCO to date (other than in terms of a cultural affinities) is as a source of security issues and challenges related

58 For instance, the Fourth Astana Economic Forum on safeguarding food security in Central Asia was held in 2011 (www.sco-ec.gov.cn/crweb/scoc/info/Article.jsp? a_no $=250767 \&$ col_no $=48$ ).

59 Boland, above n.6, 16 - noting how such economic actions "build trust and provide incentives for cooperation ... making the group more and more comprehensive regional actor ..." Ibid.

60 Troitskiy, above n.47, 44-contrasting Russia's adherence to intergovernmentality with the possibility of increased supranational SCO institutions, and suggesting this contributes to an internal SCO balance of power.

61 Konstantin Syroezhkin, Social perceptions of China and the Chinese: a view from Kazakhstan, 1(7) China and Eurasia Forum Quarterly (2009), 29-46; Elena Y. Sadovskaya, Chinese migration to Kazakhstan: a silk road for cooperation or a thorny road of prejudice?, 5(4) China and Eurasia Forum Quarterly (2007), 147-170, especially, 167; Chris Rickleton, Kyrgyzstan: China's economic influence fostering resentment, 28 April 2011 (www.eurasianet.org/node/63383). 
to sometimes violent separatist tendencies among Islamic groups, whose details will be addressed below.

38. Even if we accept that the SCO is only at the early stages of refining its institutional and administrative structures, this technical point leaves open a deeper question: Namely, how has the inside and outside of the region that constitutes this Grossraum territory been divided up, and how are the unifying elements best defined? Is this a matter of shared cultural traditions, or are material and security concerns far more important in perpetually fragile processes of regional integration? The next sections will address these questions.

\section{IV.B. An overarching cultural underpinning for the SCO?}

39. Given the emphasis of Grossraum analysis falls upon the distinctly cultural-rather than racial-biologistic - nature of regional identity and integration, it is important to address the possible "cultural underpinnings" of the SCO. This includes this body's capacity to come to terms with diversities of internal SCO cultures as part of a wider tendency to enhance communication. ${ }^{62}$ One critic has suggested that the SCO embodies only illiberal or authoritarian cultural and political norms, emphasising the political cultural dimension of the SCO as a possible unifying factor. ${ }^{63}$ However, there is reason to dispute this interpretation in that the values the SCO officially upholds in its various declarations, charters and conventions articulate principles of peaceful coexistence, multipolarity, promotion of civilisational diversity, support for internal stability and state sovereignty, and a more effective UN. These SCO values largely echo China's foreign policy discourse, thereby both endorsing and implementing its notion of regional order through the medium of the SCO.

40 Also here the wider question arises as to whether the SCO could potentially develop beyond functionalist or utilitarian approaches towards achieving an SCO identity formation based on these emerging set of values and norms, as some have argued. ${ }^{64}$ The Joint Communiqué of the Moscow Meeting of the Council of Heads of Government of SCO Member States at Astana discussed a wide range of issues related to culture, education and humanitarian affairs, and promoted consolidation of cooperation through the meeting of SCO culture ministers, which decided to establish an expert working group, and the first six-state "cultural festival" held in Kazakhstan in July 2005. In principle, enhanced cultural integration would involve addressing the motivations, concerns and expectations of the geographically smaller CA states as an element within the inclusive "SCO region" and the normative processes relating to

62 Shuyang Yanwang, Analysis on Geopolitical Characteristics of Shanghai Cooperation Organisation, 2 J. of Lanzhou University (Social Sciences), (2013), 49-55.

63 Alexander Ambrosio, Catching the "Shanghai Spirit": How the Shanghai Cooperation Organization Promotes Authoritarian Norms in Central Asia. 60(8) Europe-Asia Studies (2008), 1321-1344.

Ibid. 
the formation and reiteration of an SCO identity. ${ }^{65} \mathrm{We}$ can, therefore, recognise a range of institutional efforts to enhance regional identity, while also recognising the considerable challenges facing this integrationist project.

41. As already noted, currently, the SCO has full members from Europe (Russia) the Near East, Central Asia and South East Asia, with Iran, Pakistan and India as "observer states"-a status that is far stronger than this expression suggests as it represents a first step to full membership. ${ }^{66}$ As a result, it is difficult to appeal to a "common Asian cultural heritage" as the primary cement that binds together SCO members into a voluntary Grossraum that integrates all peoples within it.

42. Perhaps one major difference between the sense in which the EU can be considered as an evolving Grossraum and the SCO relates to the idea that a Grossraum relies upon a shared cultural tradition, which has an identifiable "inside" and "outside," such that one can generally identify where, say, Europe begins and ends, at least to some extent. The SCO, by contrast, does not or could not reasonably claim to be a Pan-Asian institution akin to how the EU now embraces all major European States (or gives associate status to say Switzerland). ${ }^{67}$ For example, viewed culturally, it is arguable that Japan is just as much an Asian nation as China or the other SCO members, perhaps more so than Russia given its geographical status as bridging Asia and eastern Europe. $^{68}$

43. On the other hand, whereas the precedent of the US Monroe Doctrine presupposed an assimilationist "melting pot" political idea operating as a source of regional integration, ${ }^{69}$ the $\mathrm{SCO}$ probably has more in common with the EU in that it brings

65 Timur Dadabaev, Shanghai Cooperation Organization (SCO) Regional Identity Formation from the Perspective of the Central Asia States, 23 Journal of Contemporary China (2014), 85.

66 Observer states participate in many of the activities of the SCO including the annual summits, and as observers at military exercises. Their position is mentioned in the regulations of the SCO Energy Club for example. Marcel De Haas, The Shanghai Cooperation Organisation's momentum towards a mature security alliance, 36(1) Scientia Militaria: South African Journal of Military Studies (2009), 15.

67 The SCO's establishment declaration refers to: "enormous potential for good-neighborliness, unity and cooperation through mutual respect and mutual trust among States belonging to different civilizations and having different cultural traditions". xinhuanet, 27 May 2005 (http://news.xinhuanet.com/english/2003-05/27/ content_889169.htm). More Generally on the EU as a possible Grossraum, see Peter Burgess, The evolution of European Union law and Carl Schmitt's theory of the nomos of Europe, in: The International Thought of Carl Schmitt, Louiza Odysseos and Fabio Petito (eds.) (2007), 185-201; Jan-Werner Müller, Constitutionalism and the Founding of Constitutions: Carl Schmitt and the Constitution of Europe, 21(6) Cardozo Law Review (2000).

68 Troitskiy, above n.47, 44.

69 Schmitt, above n.7, 99. 
together a range of states that have long-established national identities that cannot be assimilated into a single common identity. Instead, the SCO requires - and perhaps even presupposes - a shared commitment to pluralistic principles of multiculturalism and the institutionalisation of principles of mutual respect for such differences. ${ }^{70} \mathrm{At}$ the Astana summit, the SCO declared: "it is necessary to respect strictly and consecutively historical traditions and national features of every people". ${ }^{71}$ For example, while rejecting the idea that the six SCO members share a unique cultural tradition and Asian identity, it does not follow that a common culture cannot be engendered over time as a result of various institutional and other practices. For example, SCO Secretary General Nurgaliev during the Astana summit of 2009 stated that the main challenge for these states is: "to create common political, economic and informational space and to instil in the peoples of the six nations a sense of having a shared destiny". ${ }^{72}$ As recognised by the SCO members, this goal will require additional efforts: "to strengthen and expand social foundation for friendship and mutual understanding among SCO member states", which are regarded as "an important way to ensure SCO”s resilience and vitality". 73

44. In short, it is not possible to claim that the SCO is unified actually, or even potentially, by reference to a pre-existing cultural framework shared by all member states, which differentiates this regional bloc from others. If we are to identify the "glue" that could unify this institution into a genuinely regional one, we have to consider more material interests. These include a shared interest in achieving greater economic development, common security interests and provisions, health and other public services and transnational energy-as well as the next distinctly Grossraum theme: an overarching "political idea". ${ }^{74}$ Indeed, every Grossraum can only be integrated through on-going actions and a merger of social, political and cultural processes oriented towards achieving such regional integration as a common project.

70 China's Prime Minister has proposed expanding culture and people-to people exchanges. He proposed to respect cultural diversity, enhance mutual understanding among people of different countries, adding that China is willing to increase the number of scholarships for students from SCO member countries (www.chinadaily. com.cn/china/2013livisiteuasia/2013-11/30/content_17142141.htm).

71 Alyson J. K. Bailes and Paul Dunay, The Shanghai Cooperation Organisation as a regional security institution, in: Bailes et al, above n.47 8 .

72 Bolat Nurgaliev, Statement of the SCO Secretary-General Bolat K. Nurgaliev at the Security Forum of the Euro-Atlantic Partnership Council, Astana, 25 June 2009 (www.sectsco.org/EN123/show.asp?id=104).

73 Declaration on the Fifth Anniversary of the Shanghai Cooperation Organization (www.sectsco.org/EN123/show.asp?id=94).

74 Boland, above n.6, 14-16. 


\section{IV.C. Achieving regional integration through the identification of common security interests?}

45. There is considerable evidence that common security concerns represent the key unifying elements. These include imperatives relating to anti-terrorism, energy and military security, SCO-capabilities to address disasters of various kinds (including flooding), ${ }^{75}$ gaps in member states' health care provisions. ${ }^{76}$ In addition, there is the perceived need to counter-balance US power within Asia, and a shared sense of regional protective responses to region-wide threats more generally. ${ }^{77}$ In addition, there may be a shared pan-regional interest in preventing cultural differences from escalating into open and violent types of regional conflicts from which external powers can benefit through a divide and rule policy. ${ }^{78}$ As a regional organisation concerned with non-traditional security, it cannot be reduced to something akin to "The NATO of the East,",79 or the former-Warsaw Pact alliance. ${ }^{80}$ On the other hand, some have argued that there are

75 Government of Pakistan, Masood Khan Appeals to SCO to Help Pakistan with Flood Relief, Press Release No. 58, 4 September 2010, (www.pid.gov.pk/press04-09-2010. $\mathrm{htm}$ ); People's Republic of China White Paper, gov.cn web portal, China's Actions for Disaster Prevention and Reduction, 11 May 2009 (www.gov.cn/english/ official/2009-05/11/content_1310629_7.htm); Meeting of the SCO Ministers of Emergency Situations, 5 June 2009 (http://infoshos.ru/en/?idn=4347).

76 SCO Business Council website, Dmitry Mezentsev: First SCO Health Train to Come to Uzbekistan, 26 September 2007 (http://delsovet.org/?level=10\&id=43 \&lng=en); SCO Health-Care Party Left Tajikistan, 17 September 2008 (http:// bc-sco.org/?level=10\&id=538\&lng=en); Boland, above n.6, 14 .

77 Kurmat Samarkhan, SCO: RATS to Improve Anti-terror Work Through Joint Efforts of Its Member States, Dzhumanbekov, Kazinform, 9 February 2011 (www.inform. $\mathrm{kz} / \mathrm{eng} /$ article/2349905).

78 Bailes and Dunay, above n.71, 6 .

79 Maksutov, above n.12, 2.

80 On the Security dimension of the SCO, Aris has argued that the SCO: "has become the primary security organisation in Central Asia. ... tackling the so-called 'three evils' (terrorism, extremism, separatism)". This role has, he claims: "won it favour with the prevailing leaderships of its member states. ... the $\mathrm{SCO}$ is best characterised as a regional organisation concerned with non-traditional security and not as a hostile new 'Warsaw Pact' as suggested by some". Stephen Aris, The Shanghai Cooperation Organisation: 'Tackling the Three Evils.' A Regional Response to Non-traditional Security Challenges or an Anti-Western Bloc? 61(3) Europe-Asia Studies (2009), 457. For a recent claim that the 2014 "peace mission" involving 7000 military forces was a purely internal security exercise, see SCO not military alliance: PLA officer, Peoples' Daily, August 21, 2014 where Wang Ning, chief director of the mission and deputy chief of the PLA general staff claimed: "The SCO is a regional international organization in adherence to the principles of being non-aligned, non-confrontational and not targeted at any third party". (http://english.peopledaily.com.cn/n/2014/0821/ c90786-8772368.html). 
many parallels with NATO, at least in its current post-cold war form less dependent for its justification upon defining and then capitalising upon the Warsaw Pact states as a "threatening mortal enemy". 81

46. Elements of economic integration, including cooperation and infrastructure, are mediated by security issues, and therefore cannot be seen as "purely economic". ${ }^{82}$ "Energy security," for example, is increasingly identified as a vital element of SCO security policy, and this theme is gaining ground within SCO policy deliberations. The SCO provides China with a platform to meet its fast growing energy needs in a context where it has been facing a growing energy deficit and increasing oil imports from West Asia since 1993, coinciding with its massive economic growth. ${ }^{83}$ Central Asian energy resources allow China to both secure and diversify its sources, and thus maintain high degree of energy security. In July 2007, the SCO Energy Club was established to develop a common energy approach to strengthen energy security through bilateral or multilateral energy cooperation among SCO members. ${ }^{84}$ Moves have also been made toward the establishment of an "Asian energy grid" that would share and distribute regional resources. The development in 2014 of a land route of the China-Central Asia natural gas pipeline, which aims to play an important role in China's energy security, is a significant development. As de Haas notes more generally in relation to this grid: "Because this would strengthen Asian independence, it is opposed by Washington, which has tried to position itself on and around the continent to counteract those developments. $^{85}$

47. This development, together with Iranian propaganda, has encouraged Western assessments of the SCO as increasingly a geopolitical mechanism to squeeze out the historical influence of the USA and its Western allies from Central Asia, and-to this extent-to undermine Western security interests. The SCO Energy Club possibly limits Western control over global energy security — not least by means of the creation of a "gas OPEC". Whether these assessments are fair predictions, or merely reflect

81 “[T]his work will analyse the SCO's development towards a full-grown security organisation i.e., on its way to an alliance with a span of activities and a depth of cooperation similar to that of NATO". De Haas, above n.66.

82 Bailes and Dunay above n.71, 25-27; Maxim Krans, SCO Energy Club: What Will It be Like? infoshos.ru, 28 October 2009 (http://infoshos.ru/en/?idn=5040).

83 Ren Dongfeng, The Central Asia policies of China, Russia and the USA, and the Shanghai Cooperation Organization process: a view from China, Stockholm International Peace Research Institute (SIPRI), Sipree Workings Papers (2003).

84 De Haas, above n.66, 24; On recent energy developments, see SCO summit to enhance mutual trust, expand cooperation: ambassador, Peoples Daily, September 10, 2014 (english.peopledaily.com.cn/n/2014/0910/c90883-8780915.html)

85 Julien Mercille, Cruel Harvest: US Intervention in the Afghan Drug Trade. (2012), 72; Dilip Hiro, Shanghai Surprise: The Summit of the Shanghai Cooperation Organisation Reveals How Power is Shifting in the World, The Guardian, 16 June 2006. 
ideological resentment at a regional challenge to US global influence and controls, remains an open question. In short, and possibly following suit with the EU, the SCO has expanded its scope through a range of economic, finance and energy initiatives and accomplishment possessing considerable dynamism and momentum. Each of these initiatives both illustrate and promote greater intra-Grossraum organisation, planning and integration of member states into a shared regional framework. Such policies and practices have further geo-political dimensions, as well as purely economic ones, and probably raise a range of possible legal regulatory issues whose details have yet to be specified, or addressed institutionally.

\section{IV.D. A Common Political Idea?}

48. Any viable Grossraum relies upon pre-existing cultural affinities between member states, including a commitment to geopolitical multi-polarity founded upon principles of equal rights and mutual respect, including non-intervention by extra-regional powers in SCO internal affairs. ${ }^{86}$ Within SCO statements there are frequent appeals to the "Spirit of Shanghai" $" 87$ as a founding moment meriting continuation and deepening. ${ }^{88}$ The rhetoric of the "Shanghai Spirit" is taken to imply: "mutual trust, mutual benefit equality, consultation, respect for multi-civilisations and pursuit of common development". ${ }^{89}$ As Joobani notes: "[C]ontrary to some arguments that posit the SCO is devoid of normative values and principles-a focal point for critics of the SCO and its organizational structure-it should be emphasized that, since its formation in 2001, the SCO model has incorporated a normative framework ..."90

49. We agree that there are clear normative principles informing the SCO project, including the Grossraum idea of non-intervention expressed clearly in the July 2005 Astana summit declaration and elsewhere. Then at the July

2005 Astana summit, the SCO adopted a clear declaration asking countries in the U $\equiv$ coalition to withdraw their forces from Central Asia, thereby demonstrating a regional consensus regarding the exceptional nature of the western military presence in this regional zone. Yet, these are not those of Western liberalism and universalistic unipolarity, and therefore risk being misunderstood, distorted or neglected in the West. ${ }^{91}$ Arguably, in much Western discourse, the SCO is characterised reductively as a political and military block led by anti-Western Russia and China against US

86 Bailes and Dunay, above n.71, 6.

87 Boland, above n.6, 8.

88 (www.sectsco.org/EN123/brief.asp).

89 Declaration on the Fifth Anniversary of the Shanghai Cooperation Organization, 15 June 2006, Shanghai, China (www.sectsco.org/EN123/show.asp?id=94).

90 Joobani, above n.56.

91 Bailes and Dunay, above n.71, 6-7. 
and Western interests in the region. ${ }^{92}$ Ironically, this reaction mirrors the Grossraum idea that a political idea, or cluster of ideas, which are central to regional identityformation and integration around that identity will include a polemical negation of counter-principles defined as threatening. As Dadabaev recognises:

If SCO members embrace the constructivists' ideas of collective identity formation in international relations, the scheme will require common norms (expectations of behaviour, common practices and obligations), a common trajectory (shared path, past experiences, common problems and future goals), common 'others' (a common understanding of the boundaries of the 'imagined community') and common meanings (shared interpretations of values and morals that determine behaviour). In the case of the SCO ... one can already observe these elements in the efforts to create the SCO identity, such as anti-colonial, antiimperial stances, the creation of common SCO norms through the 'Shanghai spirit', cultural contacts and the SCO university scheme. At the moment, these elements of new emerging identity are comprised more of elements negating certain phenomena of international relations rather than of common norms, trajectories of development and common meanings of what the SCO represents. $^{93}$

50. There is certainly a need to consider normative aspects of how the SCO addresses international law issues of continuing national sovereignty and the relative legitimacy of its partial "pooling" in SCO wide institutions. ${ }^{94}$ Apparently, SCO nation states are more preoccupied with ensuring the stability of their territorial integrity and protecting national leaders' grip on sovereignty, ${ }^{95}$ than in either devolving all sovereignty to a super-state institution, or adopting an assimilationist political culture akin to the USA. ${ }^{96}$ Indeed, the various declarations and statements of SCO reiterate Westphalian conceptions of national sovereignty involving the "inviolable equality" among sovereign states. Equality among sovereign states has become an axiomatic political idea,

92 Oliver M. Lee, China's rise and contemporary geopolitics in Central Asia, in: Sujian Guo (ed.) China's 'Peaceful Rise' in the 21st Century (2006).

93 Dadabaev, above n.65, 11.

94 Troitskiy, above n.47, 44.

95 Bailes and Dunay, above n.71, 7.

96 Stephen Aris, A New Model of Asian Regionalism: Does the Shanghai Cooperation Organisation Have More Potential than ASEAN? 22(3) Cambridge Review of International Affairs (2009), 455. Recently, the Chinese Foreign Minister suggests that the SCO "countries should jointly guard the development paths and political systems they choose for themselves and help the SCO play a larger role in safeguarding sovereignty, security, development and other core interests of the member states ...”. Chinese FM raises five-point proposal on boosting SCO cooperation, Peoples Daily August 01, 2014 (http://english.peopledaily.com.cn/n/2014/0801/c90883-8763615.html). 
and is pledged in various SCO documents and official statements regarding regional cooperation in ways that respect the concerns of each member state. The watchwords are dialogue, consultation, mutual trust and benefit.

51. Amitav Acharya has recognised that while: "Europeans increasingly live in a postsovereign world, believing it to be more efficient and morally desirable; Asia remains firmly beholden to sovereignty, taking it as the fundamental basis of their stability and identity". ${ }^{97}$ As a result of this axiomatic political idea, the SCO adopts a different model of cooperation from the $\mathrm{EU}$ that is not based upon supra-nationalism. Instead, as noted by Narine with regard to the states of East Asia: "the regional attitude towards multilateral institutions is that they should assist in the state-building process by enhancing the sovereignty of their members". ${ }^{98}$ Therefore, in contrast to Western organizations: "Asian regional organisations are geared to sovereignty enhancement, not sovereignty pooling". ${ }^{9}$

52. A particular example of this has been the reluctance of the SCO to intervene within internal rebellions within the smaller Asian states, even on "humanitarian" grounds, such as the UN's fabled "Responsibility to Protect". ${ }^{100}$ Most recently, on the UN Security Council China did not support Russian military adventures into the Crimean region that clearly violated Ukrainian sovereignty. SCO members have noted this point concerning the centrality of national sovereignty, claiming the SCO aims to contribute to the establishment of a new forms of international architecture based on respect for the: 'right of all countries to safeguard national unity and their national interests, pursue particular models of development and formulate domestic and foreign policies independently and participate in international affairs on an equal basis". ${ }^{101}$

53. This desire to bolster, rather than sacrifice, national sovereignty which is also related to internal security concerns, lies at the heart of the distinction between Asian regional cooperation and the EU's policy of regional integration towards an ever closer political union, which in places proves counterproductive. Indeed, it can be considered a powerful shared "political idea" in the specifically Grossraum sense

97 Stephen Aris, The Response of the Shanghai Cooperation Organisation to the Crisis in Kyrgyzstan, 14(3) Civil Wars (2012), 451-476. See also Acharya Amitav, Europe and Asia: reflections on a tale of two regionalisms, in: Bertrand Fort and Douglas Webber (eds.) Regional integration in East Asia and Europe: convergence or divergence? (2006), 312-322.

98 Ibid. See also Shaun Narine, State sovereignty, political legitimacy and regional institutionalism in the Asia-Pacific, 17(3) The Pacific Review (2005), 423-450.

99 See Richard Higgott, De facto and de jure regionalism: the double discourse of regionalism in the Asia Pacific, 11(2) Global Society (1997), 65-83.

100 Aris, above n.97.

101 Declaration on the Fifth Anniversary of the Shanghai Cooperation Organization (www.sectsco.org/EN123/show.asp?id=94). 
discussed above. This overarching idea also highlights the broadly similar outlook or orientations with which the frameworks of ASEAN and SCO have been constructed. These frameworks place the key concerns of the member states' leaderships, regime security and sovereign enhancing regional cooperation at the heart of these organisations.

54. For example, China has certainly engaged with Central Asia at least partly to stabilise its economically important Western border province of Xinjiang, which borders Kazakhstan, Kyrgyzstan, and Tajikistan, and where much trading activity takes place. However, this province remains challenged by various security issues.

55. The SCO's original purpose and rationale was to peacefully solve a number of actual and possible disputes on border issues. Its objectives are set out in part in the preamble and Art. 1 of this organisation's founding Charter. In particular, the preamble refers to both common security interests and pre-existing, cross-border cultural affinities: "Based on historically established ties between their peoples' and the goal of "Striving for further enhancement of comprehensive cooperation" as well as "Desiring to jointly contribute to the strengthening of peace and ensuring of security and stability in the region in the environment of developing political multi-polarity and economic and information globalization". 102 The other main political goals of the SCO defined in its founding Charter relate to both internal and external SCO policies, namely: "promoting effective cooperation in politics, trade and economy, science and technology, culture as well as education, energy, transportation, tourism, environmental protection and other fields; ... moving towards the establishment of a new, democratic, just and rational political and economic international order". ${ }^{103}$ The latter implies a commitment to regional pluralism and multipolarity, and thus a polemical rejection of superpower unilateralism, as a shared principle of legal ordering between Grossraum. Within the current SCO, the idea of a mutually supporting form of economic development across Central Asia, including through shared energy policies and other coordination of trade, ${ }^{104}$ together with regional security cooperation, can also be identified as key elements of this possible Grossraum's distinctive "political idea". For example, at the 2005 Summit the Heads of State proclaimed:

[A] gainst the backdrop of a contradictory process of globalisation, multilateral cooperation, which is based on the principles of equal right and mutual respect, non-intervention in internal affairs of sovereign states, ... call upon the international community, irrespective of its differences in ideology and social

102 (www.sectsco.org/EN123/brief.asp).

103 Ibid

104 Nicklas Norling, and Niklas Swanstrom, The Shanghai Cooperation Organization, Trade, and the Roles of Iran, India, and Pakistan, 26(3) Central Asian Survey (2007) (www.silkroadstudies.org/new/docs/publications/2007/CAS-SCO.pdf). 
structure, to form a new concept of security based on mutual trust, mutual benefit, equality and interaction. ${ }^{105}$

In one respect then, this emphasis on mutual respect, rather than assimilation, represents a reaffirmation of the pluralism of classic Grossraum thinking, specifically, the notion of an underlying "political idea".

\section{IV.E. Military-Security forms of regional integration? ${ }^{106}$}

56. Any Grossraum relies upon a politically acceptable and mutually beneficial "security guarantees" relating to both internal and external security threats provided by a "leading power" who possesses adequate material resources. Thus, another defining feature of a Grossraum is the effective prohibition and deterrence of extra-regional military interventions. This has to be enforced not merely as a transnational legal norm but also through military and related security and intelligence capabilities stemming from the "leading power's" relative material strengths. The leading power must mobilise a polemical geo-political element in which the SCO distinguishes between its perceived "friends," "neutrals" and potential "enemies".

57. In addition, to remain viable a Grossraum needs to protect its own integrity from paramilitary and terroristic attacks, a counter-terrorist dimension that has the by-product of enhancing intra-Grossraum security cooperation against those "secessionists" defined and self-defined as "enemies within," which may also contribute to processes of joint military cooperation and regional identity formation and integration more generally. ${ }^{107}$ The following section addresses both these external and internal security elements of SCO activities. ${ }^{108}$

58. Non-traditional security threats range deeply affecting SCO member states range from terrorism, separatism and "extremism" to drug-trafficking, trans-border crime, to HIV and other epidemics and illegal migration. In turn, such perceived threats have led to a policy consensus and community of security interests among SCO members. The SCO's 2007 Bishkek Declaration provides a very broad definition of security, which includes the stability of world economy, reduction of poverty, creating parity in the

105 Declaration of Heads of Member States of SCO, 12 June 2006 (updated) (www. chinadaily.com.cn/china/2006-06/12/content_6020345.htm)

106 For a useful summary see Boland above n.6, 11 - 13; Zhongguo Xiandai Guoji Guanxi Yanjiusuo, China Contemporary International Relations Institute (ed.) Shanghai Hezuo Zuzhi: Xin Anquanguan yu Xin Jizhi, Shanghai Cooperation Organisation: New Security Perceptions and System (2002).

107 As Timur Dadabaev notes: "during the initial years of cooperation, the SCO members had a better understanding of their common vision for clear, defined security goals (fighting militant religious groups, border issues and opposition to the US presence in the region), which brought these states closer to each other at the time of inception". Dadabaev above n.65, 5 .

108 Cf. Aris, above n.80. 
social and economic development levels, maintaining the economic, environmental, energy, informational security, as well as protection from natural and technological disasters. It also identifies energy as a major security component in the Central Asian Security scenario and advocates optimal cooperation among the member states in this field.

59. Here, we need to recall that the US possesses and has recently strengthened its military bases in central Asia that largely encircle China. American troops and military alliances in Central Asia, India and Afghanistan amount to the western arc of a containment strategy, one that also relies on cooperation with nations in East and Southeast Asia. ${ }^{109}$ The US attaches great strategic significance to central Asia due to rapid actual and potential growth of international terrorism and its interests in energy resources. This superpower has also created bilateral alliances with most of the regimes in this region, providing it with military bases in Central Asian republics.

60. Both Moscow and Beijing have viewed the expansion of these as part of a potentially dangerous and broader unilateral development in US security policy beginning under the Bush administration. ${ }^{110}$ Writers have noted the possibility of the SCO developing its security apparatus into a counterweight to American military power in Asia, pushing back and deterring such "extra-regional interventions" in ways that accord with classic Grossraum imperatives related to material equilibrium. ${ }^{111}$ In turn, this could be interpreted as raising the question of the SCO's positive contribution to maintaining a global equilibrium, or balance of power, which restricts and offsets Western tendencies towards imperialistic unilateralism.

61. Cooley argues that the Chinese domestic security imperative of combating the "three evils" has been directly transplanted into the founding language of the SCO Charter as its guiding principle of "security cooperation". 112 Certainly China's

109 Edward Wong, China Quietly Extends Footprints Into Central Asia, New York Times, 2 January 2011, (http://www.nytimes.com/2011/01/03/world/asia/ 03china.html); Q\&A: U.S. Military Bases in Central Asia, New York Times, 26 July 2005, (http://www.nytimes.com/cfr/international/slot2_072605.html); Jim Nichol, Kyrgyzstan and the Status of the U.S. Manas Airbase: Context and Implications, Congressional Research Service, 1 July 2009: (http://www.fas.org/sgp/crs/ row/R40564.pdf).

110 Ariel Sznajder, China's Shanghai, 5 Jnl. of the IPS (2006), 100-01.

111 Hamid Golpira claims that one of the motivations behind the SCO is: "the real objective of counterbalancing the activities of the United States and NATO in Central Asia," Tehran Times, November 20, 2008; Gene Germanovich, The Shanghai Cooperation Organisation: A Threat to American Interests in Central Asia, 6(1) China and Eurasia Forum Quarterly (2008), 19-38.

112 Cooley, above n.3, 77. 
"New Security Concept" emphasises non-interference, multipolarity and pluralism, and thus dovetails into Grossraum thinking. ${ }^{113}$

62. SCO members often claim that this organisation is primarily designed for political and economic cooperation, and that military coordination plays only a small role, and there is some evidence for this. ${ }^{114}$ For instance, the Russian Deputy Defence Minister, Sergei Razov, has denied allegations that military cooperation among SCO members is a top priority and stated that economic cooperation and internal security are the main interests. ${ }^{115}$ On 17 August 2007, Russia's President Putin re-affirmed this position. ${ }^{116}$

63. Yet, it is arguable that, since 2002, the military exercises of the SCO, have: "become increasingly ambitious, developing from a bilateral or multilateral level to a joint all-SCO level, and including not only counter-terrorism but also external security policy connotations". ${ }^{117}$ The SCO's Bishkek Declaration, signed on 26 August, 2007, very clearly delineates this body's security vision. It insists that material regional development and regional security are interconnected, suggesting that each requires multilateral not unilateral efforts to resolve modem security problems.

64. Before the 2007 Bishkek Summit, the SCO Ministers of Defence agreed a structural arrangement for joint military exercises. According to the Kyrgyz Defence Minister, Ismail Isakov, this agreement lays the long-term organisational and legal foundations for such activities in the future. ${ }^{118}$ The 2006 Shanghai Summit re-affirmed that, in case of "threats to regional peace, stability and security," SCO members would be duty bound to engage in immediate consultations to devise effective responses to this state of emergency. The

113 Ministry of Foreign Affairs of the People's Republic of China, China's Position Paper on the New Security Concept, 31 July 2002, (http://www.fmprc.gov.cn/ce/ceun/ eng/xw/t27742.htm)

114 Maksutov, n.12 above, 7 noting that: "military cooperation is probably the most limited field of development within the SCO framework ..." See also Richard Weitz, Shanghai Summit fails to yield NATO-style defence agreement, 18(8) Janes Intelligence Review (2006), 40-43.

115 Quoted in De Haas, above n.66, 16.

116 Franz W. Stakelbeck Jr., The Shanghai Cooperation Organization, FrontPageMagazine.com, 8 August 2005 (www.frontpagemag.com/Articles/Printable.asp? ID =19041); ShOS ne nado sravnivats NATO, schitayet Putin, RIA Novosti, 17 August 2007; Richard Weitz, above n.114, 41-42.

117 De Haas, above n.66, 17.

118 SCO Defence Ministers gather in Bishkek, 27 June 2007, (www.sectsco.org/html/ 01465.html); SCO member states to increase defense co-op, Xinhua, 27 June 2007; Karniol, China, Russia expand “Peace Mission 2007”, 25 July 2007. See also de Haas, above n.66; 17; Roger N. McDermott, The Rising Dragon: SCO Peace Mission 2007, Jamestown Foundation, October, 200) (www.jamestown.org/uploads/ media/Jamestown-McDermottRisingDragon.pdf); Peace Mission 2010 concludes, opens new page for SCO cooperation, Xinhua, September 25, 2010 (news.xinhuanet.com/english2010/world/2010-09/25/c_13529321.htm). 
projected drafting of security mechanisms to achieve this NATO-style policy, was repeated at the 2007 Bishkek Summit, ${ }^{119}$ and seems to have become a regular fixture ever since. ${ }^{120}$

65. There is evidence, then, that from 2003, the SCO's activities have been expanded to include increased integration in the form of military cooperation and security-related intelligence sharing, and that these have involved a number of SCO joint military exercises. Under the SCO auspices, in 2005 China and Russia engaged in joint large-scale war games termed "peace missions, repeated in 2007 (at Chelyabinsk Russia), and in 2014. ${ }^{121}$ In mid-2009, the SCO held a major joint military exercise in China's Shenyang province, involving tanks, fighter jets and 3,000 soldiers. Later a "Peace Mission 2010" was conducted between September 9-25 at Kazakhstan's Matybulak training area, involving personnel from China, Russia, Kazakhstan, Kyrgyzstan and Tajikistan in joint planning and operational maneuvers. ${ }^{122}$ The SCO war games have also served as a platform for making larger military announcements by members, including during the 2007 war games in Russia, where President Putin announced a resumption of Russian strategic bomber patrols. ${ }^{123}$ By reassuring the Central Asian governments that they can depend on Russia and China to protect them from external threats (as opposed to internal unrest or civil unrest, the peace missions may have weakened Western influence in the region by helping persuade these governments that they need not rely on US-led NATO for their defense. These manoeuvres also signal communicate to extra-regional audiences, particularly those in Washington and Brussels,

119 Declaration on Fifth Anniversary of Shanghai Cooperation Organisation, 15 June 2006 Shanghai; Joint Communiqué of meeting of Council of Heads of SCO Member States, 16 August 2007. (www.sectsco.org/EN123/show.asp?id=93).

120 See for example (http://usa.chinadaily.com.cn/world/2013-11/21/content_ 17119719.htm)

121 De Haas, The "Peace Mission 2007" Exercises: The Shanghai Cooperation Organisation Advances, Defence Academy of the United Kingdom, Central Asian Series, September 2007, (www.clingendael.nl/publications/2007/20070900_cscp_ paper_haas.pdf). The 2014 event took place in north China's Inner Mongolia on August 24. A total of 7,000 troops from China, Russia, Kazakhstan, Kyrgyzstan and Tajikistan participated, including ground and air forces, special operations and airborne troops and others tasked with electronic countermeasures, reconnaissance, mapping and positioning. This mission was a multinational drill with three phases, troops deployment, battle planning and simulated combat. (http://english.peopledaily. com.cn/n/2014/0825/c90883-8773946.html; http://english.peopledaily.com.cn/ $\mathrm{n} / 2014 / 0818 / \mathrm{c} 90786-8771091 . \mathrm{html}$ ).

122 Boland, above n.6. The five national armed forces sent approximately 5,000 combat troops and hundreds of pieces of military hardware including tanks and armoured personnel carriers as well as warplanes and helicopters. Richard Weitz, China's Growing Clout in the SCO: Peace Mission 2010, 10(20) China Brief, October 8, (2010).

123 Fred Attewill, Putin Orders Resumption of Strategic Bomber Flights, Guardian, 17 August 2007 (www.guardian.co.uk/world/2007/aug/17/russia.usa). 
that-as joint leading powers of the an Asian Grossraum - both Moscow and Beijing consider Central Asia as falling within their overlapping zones of security responsibility.

66. On the other hand, there have been some internal tensions within the SCO. In 2007, for example, China, while sending its troops to Central Russia to participate in an SCO security exercise, was denied permission from the Kazakh government to use its territory as conduit point. ${ }^{124}$ Also, the overlap between SCO membership and the Collective Security Treaty Organisation (CSTO), where Russia plays the major role, ${ }^{125}$ has caused some internal friction over security policy, with Russia pressing for greater SCO involvement against China's opposition. ${ }^{126}$ CSTO is an overtly anti-American formation, to which all SCO members belong apart from China, which is aimed at repulsing potential military attack and providing for the mutual defines of its members. Another source of security fragmentation is the CIS Collective Security Treaty (between Armenia, Belarus, Kazakhstan, Kyrgyzstan, Russia, and Tajikistan) who agreed in their Yerevan meeting of 2001 to create a rapid-reaction force to fight "terrorists" and "extremists". ${ }^{127}$

67. One possible early move would be to create SCO rapid reaction forces to deal with terrorist attacks and their aftermath. This could arise as part of the SCO's evolution towards a mature security organisation, as well as the emergent cooperation with the

124 Hansen Flemming Splidsboel, The Shanghai Co-operation Organisation: Probing the Myths, 8 Royal Danish Defence College Journal (2008) (www.forsvaret. dklFAKIPublikationer/Briefs/Documents); (http://english.peopledaily.com.cn/ n/2014/0909/c98649-8780180-2.html)

125 Alexander Frost, The CSTO, the SCO, and Russia's Strategic Goals in Central Asia, 7 (3) China and Eurasia Forum Quarterly (2009, (www.chinaeurasia.org/images/ stories/isdp-cefq/CEFQ200910/cefq7.3af83-102.pdf).

126 SCO-CSTO Merger Raised at Dushanbe Conference, 04 June 2014 (http://www. cacianalyst.org/publications/field-reports/item/12983-sco-csto-merger-raised-atdushanbe-conference.html); CSTO proposes to SCO joint effort on post-conflict Afghanistan, RIA Novosti, July 2007; Joint Communique of meeting of Council of Heads of SCO Member States, 16 August 2007 (www.sectsco.org/html/01651. html); Ivan Safranchuk, ShOS na marshe. ODKB v oboze?, Nezavisimoye Voyennoye Obozreniye, 24 August 2007, 3; Security alliances led by Russia, China linkup, Daily Times, 6 October 2007 (http://www.oneindia.com/2007/10/05/ security-alliances-led-by-russia-china-link-up-1191584987.html); Victor Litovkin, ODKB i SMI protiv terrorisma, Nezavisimoye Voyennoye Obozreniye, 2 November 2007, 1; Consultations held by SCO and CSTO Secretariats, 4 December 2007 (www.sectsco.org/EN123/show.asp?id=120) and (www.sectsco.org/html/01915. html); Sergai Blagov, Eurasian groupings seek closer security ties, ISN Security Watch, 13 December 2007. More generally on Chinese-Russian relations within the SCO see Phunchok Stobdan, Shanghai Cooperation Organization: challenges to China's leadership', 4(32) Strategic Analysis (2008), 527-547.

127 Peimani Hooman, Failed Transition, Bleak Future? War and Instability in Central Asia and the Caucasus (2002), 103. 
CSTO, and the recently created SCO Energy Club whose extensive oil and gas pipelines are potentially vulnerable to terrorist attack. For these reasons, the SCO may now have an interest in developing its own standing reaction forces under a coordinated military command that mirrors aspects of NATO. ${ }^{128}$ On the other hand, any wider comparison with NATO needs to recognise many vital differences, such as the absence of legally binding and treaty-based mutual defence guarantees. ${ }^{129}$ In 2014, China's President Xi Jinping proposed at the September SCO Council of Heads of State in the Tajik capital of Dushanbe, Xi that the SCO states each had a "common responsibility and mission to bring more security and benefit to the SCO member states and their people," and that "Currently, (we) should focus on combating religion-involved extremism and internet terrorism". In additional to enhancing existing security mechanisms, he suggested the SCO members launch consultation on an anti-extremism convention and initiate studies on a mechanism for actions against internet terrorism. The president also called on the SCO members to grant the group's Regional Counter-Terrorism Structure (RCTS) new function to combat drug trafficking at an early date. ${ }^{130}$

68. Through the SCO, China has engaged with Central Asia on security grounds at least partly to stabilize its economically important Western border province of Xinjiang. ${ }^{131}$ This province, which borders Kazakhstan, Kyrgyzstan, and Tajikistan, has long been affected by the political and paramilitary activities of members of Uighur ethnic minority groups seeking separation from China, who aim to create a distinctly Islamic Republic. ${ }^{132}$ Separatism affecting Xinjiang would deprive China of over

128 De Haas, above n.66, 26 More generally on the SCO's security dimension that goes beyond purely military issues, Pan Guang, AChinese Perspective on the Shanghai Cooperation Organisation, in: Bailes et al., above n.47, 45-58.

129 Boland, above n.6, 13.

$130 \mathrm{Xi}$ makes four-point proposal for SCO development, Shanghai Daily, 13 September 2014 (www.shanghaidaily.com/national/Xi-makes-fourpoint-proposal-for-SCOdevelopment/shdaily.shtml)

131 Suisheng Zhao, China's approaches toward regional cooperation in East Asia: motivations and calculations, 20(68) Journal of Contemporary China (2011), 53-67.

132 These attacks have included a May 1998 bus bombing in Osh, the March 2000 assassination of the leader of the Uighur émigré community in Kyrgyzstan, and a May 2000 attack on a Chinese delegation visiting Kyrgyzstan. See James Milward, Eurasian crossroads: a history of Xinjiang, 191 The China Quarterly (2007), 755-791. On the rise and decline of Uighur violence after 1997, see James Milward, Violent Separatism in Xinjiang: A Critical Assessment, East-West Center Washington, Policy Paper 6 (2004) (www.eastwestcenter.org/fileadmin/stored/pdfs/PS006.pdf). For an overview, see Chien-peng Chun, China's "War on Terror": September 11 and Uighur Separatism, 81(4) Foreign Affairs (2002), 8-9. More generally, see Stephen Frederick Starr (ed.) Xinjiang: China’s Muslim Borderland, (2004). 
$15 \%$ of its territory away, cutting it off from Central Asia, removing it of its nuclear testing grounds and the vital oil and natural gas and gold reserves in the Tarim basin. ${ }^{133}$

69. In October 2007, the SCO signed an agreement with the CSTO in the Tajik capital Dushanbe to broaden out security cooperation on drug trafficking and transnational crime more generally. ${ }^{134}$ The organisation is also addressing cyber-warfare and "information warfare"-where external forces seek to undermine another's "political, economic, and social systems". ${ }^{135}$ Indeed, China's initial drive for the creation of SCO corresponded with the increased terrorist violence in this western province as well as the Central Asian states and the Russian province of Chechnya. The Xinjiang area contains peoples who are predominantly of Turkic origin, consisting of Central Asian ethnic groups-mainly Kazakhs, Uyghurs (Uighurs), and, to a lesser extent, Kyrgyz. ${ }^{136}$ This regional faces particular issues with minority groups spanning the borders of China, and there is the question of whether further concessions to these religious groups could either these security issues related to militant secessionism, or, by positively reinforcing such identities, actually intensify them. ${ }^{137}$ This is not an issue that classic Grossraum theory has yet successfully addressed, and perhaps such issues are inherently particularistic and incapable of resolution at the level of general Grossraum principles of mutual respect for difference? These secessionist groups include the East Turkistan Islamic Movement (ETIM), the East Turkistan Liberation Organization (ETLO), and the Uighur Liberation Organization (ULO), and have contributed to over 200 bombings and assassinations killing 164 people and wounding 440 others. ${ }^{138}$ On 1 March 2014, there was a major atrocity by such separatists in the city of Kunming involving concerted knife attacks on civilians outside a train station, leading to 29 deaths and many more

133 Habova Antonina, The Shanghai Cooperation Organisation: a New regional Mechanism for Combating Terrorism, Ethnic Separatism, And Religious Extremism (2003) 92 (http://www.iris-bg.org/files/Chapt4.pdf).

134 (www.en.wikipedia.org/wiki/Collective_Security_Treaty_Organization)

135 Kazakhstan Notes Afghanistan's Emerging Security Agenda, Eurasia Daily Monitor Review (www.jamestown.org/regions/centralasia/single/?tx_ttnews\%5Bpointer\% 5D=75\&tx_ttnews\%5Btt_news\%5D=33237\&tx_ttnews\%5BbackPid\%5D=53\& cHash=7d67dae37bf2f714ca6255005743f939\#.VGc09I33vp8); Tom Gjelten, Seeing the Internet as an "Information Weapon," National Public Radio, September 23, 2010. (www.npr.org/templates/story/story.php?storyId=130052701).

136 Hooman, above n.127, 79.

137 Sznajder, above n.110, 93.

138 Cooley, above n.3, 76; Anna Malikova, Uzbek Islamic Movement Considered a Threat to Asian Security, Central Asia Online, 23 April 2009 (www. centralasiaonline.com/en_GB/articles/caii/features/2009/04/23/feature-02). 
serious injuries. ${ }^{139}$ In response, the SCO issued a strong statement of condemnation. ${ }^{140}$

70. Given such security challenges, China has sought to enlist regional cooperation for this and other aspects of its wider security and economic agenda. ${ }^{141}$ Prompted, in part, by the post-9/11 US-led "war on terror" initiatives, during the first half of 2002 Chinese diplomats scheduled numerous SCO coordination meetings and summits. These addressed the topics of Afghanistan, border guards, counterterrorism, as well as cultural and economic ties. At the June 2001 SCO meeting, the Chinese expressed their fear of the growth of "extremism" in Afghanistan, which could destabilisese all of Central Asia and the neighbouring Chinese province. ${ }^{142}$

71. At the important June 2002 annual SCO summit in Saint Petersburg, SCO members signed an agreement establishing the SCO regional antiterrorism structure (RATS). ${ }^{143}$ From 2004, RATs has been based in Tashkent Uzbekistan acting as a centre for security cooperation, information pooling, and exchange and monitoring of the SCO's Anti-Terrorism Treaty. RATS is a permanent standing organ of the SCO. ${ }^{144}$ It serves to promote cooperation of member states against "the three evils" of terrorism, separatism and extremism, which are run together in a rejection of liberalism's ideological preferences. RATS's work is particularly focused on the priorities of SCO members: Uighur

groups for China; Chechen groups for Russia; and Hizb ut-Tahrir and the Islamic Movement of Turkistan for Uzbekistan, Tajikistan and Kyrgyzstan. On 21 April 2006, the SCO announced plans to fight cross-border drug crimes under the SCO's rather elastic counter-terrorism framework. Since its establishment 10 years ago, the Anti-Terrorism Structure has provided a regional platform for law enforcement and security cooperation among members countries with rising international profile and influence. Over the past decade, SCO members have signed over 300 documents regarding law enforcement and security and held over 10 anti-terrorist exercises. Priorities have included transnational drug control, border defence, security at major international events and cyber security, as well as targeting terrorist financing. ${ }^{145}$

139 (www.bbc.co.uk/news/blogs-china-blog-26380542);

140 See Statement of SCO Secretary-General in connection with terrorist act at Kunming railwaystation: Demitri Mezentsev SCO Secretary-General Beijing, 3 March 2014: (http://www.sectsco.org/EN123/show.asp?id=502).

141 Cooley, above n.3, 75; David Kerr, Strategic Regionalism: Central Asian and Russian Perspectives on China's Strategic Re-emergence, 86(1) International Affairs (2010), $127-152$.

142 Hooman, above n.127, 120.

143 Cooley, above n.3, 81.

144 This topic is addressed by Maksutov, above n.12.

145 Plan of Action of the Shanghai Cooperation Organization Member States and the Islamic Republic of Afghanistan on Combating Terrorism, Illicit Drug Trafficking 
72. After the Secretariat, the RATS is SCO's most important institution. Its work includes information exchanges, extradition and the co-ordination of operations, as well as the targeting of terrorist training camps and finance. Vyacheslav Kasymov, deputy head of Uzbekistan's security service, was appointed as the first director of RATS with a staff of 30 officials, coming from all the SCO members. RATS has recently expanded its role to embrace the harmonisation of antiterrorist legislation in the member-states, compiling common lists of terrorist organisations and key "terrorists," and tracking the financing of "terrorist bodies". ${ }^{146}$ In spring 2006, RATS held antiterrorism exercises in Uzbekistan which included personnel from Special Forces, law enforcement bodies, and troops from SCO member states. ${ }^{147}$ Two years later, the SCO organised anti-terrorism training exercises in Russia's Volgograd Refinery (albeit without Chinese participation ${ }^{148}$ and in 2009 another similar "Norak-antiterrorism" exercise was held. ${ }^{149}$ In addition, a range of cross-border types of criminality, including narcotics cyber-crime, natural and man-made disasters and human trafficking are now being addressed under the auspices of an enlarged SCO security agenda. ${ }^{150}$ Arguably, in this state security respect (as opposed to regular forms of regional police mutual assistance), ${ }^{151}$ the SCO is further down the path of becoming a full Grossraum than the EU.

and Organized Crime, 27 March 2009 (www.sectsco.org/EN/show.asp?id=99; www.mid.ru/Brp_4.nsf/arh/E3D58AFDD2019131C3257586005C652C?Open Document); Bahrom Mannonov, Tajik Leader Offers Establishment of SCO Regional Antidrug Center in Dushanbe, asiaplus.tj, 26 July 2008 (http://news.tj/en/news/ tajik-leader-offers-establishment-sco-regional-antidrug-center-dushanbe); China calls for SCO security efforts (Xinhua) June 18, 2014 (http://english.peopledaily. com.cn/n/2014/0618/c90785-8743206.html).

146 See Oksana Antonenko, The EU should not Ignore the Shanghai Cooperation Organisation, Centre for European Reform, May 2007, 4.

147 CEF Weekly Newsletter, 11 China and Eurasia Forum, 6-12 March 2006, (www. silkroadstudies.org/new/docs/CEF/Weekly/March_6-12_2006.pdf).

148 Lukoil press release, Volgograd Refinery Hosted International Anti-Terrorism Exercises, 4 September 2008 (www.lukoil.com/press.asp?div_id=1\&id=2921).

149 Norak-Antiterror is Military Training for SCO Anti-Terrorist Forces, 23 April 2009 (infoshos.ru/en/?idn=4086).

150 Boland, above n.6, 4, 16; Kurmat Samarkhan, SCO RATS to Improve Anti-terror Work Through Joint Efforts of Its Member States - Dzhumanbekov, Kazinform, 9 February 2011 (www.inform.kz/eng/article/2349905); Agreement Between the Governments of the Member States of the Shanghai Cooperation Organization on Cooperation in the Field of International Information Security, 2 Dec 2008, (http:// media.npr.org/assets/news/2010/09/23/cyber_treaty.pdf).

151 Ruslan Suleimenov, SCO-Important Forum to Find Solutions for Regional Security Challenges, Kazinform, 28 December 2009: (www.inform.kz/eng/ article/2223613). 
73. In international forums, such as the $\mathrm{UN}$, the $\mathrm{SCO}$ tries to present a united common position on definitions of "terrorism" or lists of banned organisations. ${ }^{152}$ However, in practice, officials at RATS typically report not to the SCO Secretariat in Beijing, but rather to their respective government ministries. ${ }^{153}$ There is also a Chinese preference for a bilateral form of interstate intelligence sharing, even with the USA. This indicates that on state security issues, there may still be a continuing reluctance of SCO member governments to fully delegate the details of security and intelligence to a SCO-wide institution to which all members have access. This sovereignty-oriented stance largely mirrors the position in the EU. ${ }^{154}$

74. Cooley recognises that, during its first decade, the SCO: "has been most effective in the area of security cooperation, especially internal security. Member countries have successfully concluded and ratified a security treaty, established an anti-terrorism centre and forum, and coordinated their efforts to combat transnational threats in the region". ${ }^{155}$ Certainly, the SCO has benefited in one sense from the US-led "War on Terror," which has created a context in which separatist and nationalistic paramilitary violence within the Xinjiang province can be assimilated into the broad enmity category of "Islamicist terrorism". One distinctly geopolitical effect has been to partly neutralise official Western criticism predicated upon liberalism's often inconsistent ideological differentiation of militant dissent and political opposition from criminality. ${ }^{156}$

75. One possible difficulty of the SCO's security structure from a Grossraum perspective is that some but not all SCO states are active members in CSTO, ${ }^{157}$ which includes Russia but not China, and also includes two non-SCO members: Belarus and Armenia. In this sense, SCO security policy is fragmented, with some members possessing dual commitments and regional treaty obligations outside this body. As a result, there is a remarkable combination of unilateralism, bilateralism

152 Oksana Antonenko, The EU should not Ignore the Shanghai Cooperation Organisation, Centre for European Reform, May 2007, 4-arguing for stronger EU-SCO links. 'By working with the SCO, the EU could help stabilise Central Asia, improve its energy security and strengthen its efforts to fight terrorism and drug-trafficking.' (www.cer.org.uk/sites/default/files/publications/attachments/pdf/2011/ policybrief_sco_web_11may07-809.pdf).

153 Cooley, above n. $3,78$.

154 Ibid, 80.

155 Roger McDermott, The Shanghai Cooperation Organization's Impact on Central Asian Security, 59(4), Problems Of Post-Communism (2012) 56-65; Cooley, above n.3, 79 .

156 Cooley, above n.3, 80.

157 In May 2002, the historical 1992 Collective Security Treaty was formally re-established by the Presidents of Armenia, Belarus, Kazakhstan, Kyrgyzstan, Russia, and Tajikistan, but without Uzbekistan. 
and multilateralism in SCO members' responses to terrorism. ${ }^{158}$ In turn, this could cause conflicts of interest, particularly in the event of military clashes within Eurasia. It is, perhaps, difficult to reconcile this fragmentation with the integrated security apparatus of a fully developed Grossraum where all members would equally participate in regional security to the forceful exclusion of other regional organisations. ${ }^{159} \mathrm{On}$ the other hand, insofar as NATO possesses some of the characteristics of a Grossraum, its members also have divided loyalties. Furthermore, there may also be a danger in focusing only upon the security contributions of the twin "leading powers" without reference to their partial and still unfolding integration a wider SCO-wide security agenda that we have discussed above. ${ }^{160}$

\section{IV.F. Integration and the SCO's twin "Leading Powers"}

76. Grossraum analysis affirms that a "leading power" (or powers) will have to take on the onerous role of acting as a protector or security guarantor for the other member states, and contribute more extensively to various forms of agreed integration, including economic and security forms. Grossraum theory to date tends to assume the existence of a single "leading power" operating as in part the regional security guarantor for other members. However, with respect to the SCO, there is no disguising the fact that the PRC and Russia represent twin "leading powers". This is even reflected in the choice of "official languages" of Russian and Chinese outlined by Art. 20 of the SCO Charter. In addition, the strong leading role of the PRC is clear from how, under Art. 18, member States must appoint their permanent representatives to the SCO Secretariat, who are members of the diplomatic staff of the embassies of the member States in Beijing. In addition, although the key post of Secretary General is rotated, the first was Chinese, followed by a Russian official. ${ }^{161}$

158 Farkhod Tolipov, Multilateralism, Bilateralism, and Unilateralism in Fighting Terrorism in the SCO Area, 4(2) China and Eurasia Forum Quarterly (2006) (www. silkroadstudies.org/new/docs/CEF/Quarterly/May_2006/Tolipov.pdf). More generally on the rise of multilateralism in Chinese foreign policy, see Gilbert Rozman, Post Cold War evolution of Chinese thinking on regional institutions in northeast Asia, 19 (66) Journal of Contemporary China (2010), 605-620.

159 Sznajder, above n.110, 100-101. Kazakhstan has signed an Individual Partnership Action Plan with NATO, while Kyrgyzstan has extended the lease of Manaz air base to the US contrary to SCO opposition to foreign military bases on its members' soil. Tajikistan provides facilities for the armed forces of France, as does Uzbekistan for those of Germany.

160 Roger N. McDermott, The Shanghai Cooperation Organization's Impact on Central Asian Security, 59(4) Problems of Post-Communism (2012): 56-65.

161 Guangde Zhang, the first Secretary General; Currently Dmitry Fedorovich Mezentsev, a former professor with contextually appropriate specialism in political psychology, and a recipient of a medal for the strengthening of Russo-Chinese friendship, (www.sectsco.org/EN123/secretary.asp). 
77. In the post-Cold War era, a lack of open conflict within Chinese-Russian relations is vital strategically and their operation in tandem as twin "leading powers" within the SCO meets many the specific interests of both states, a number of which such as security imperatives within Central Asia, converge. Improving relations with Russia also forms part of the Chinese grand strategy both at the global and regional levels, not least because Russian is likely to retain its dominant influence in this region rendering it both counterproductive and strategically to compete with Russia. Instead, China prefers to interpret the US as their joint rival competition in the Central Asian zone.

78. Mutual accommodation and "strategic partnership" with Russia in Central Asia also assists China to pursue its own vital energy related goals in this region, provides additional resources to both contest Uighur separatism and modernise its military forces. ${ }^{162}$ These interests have resulted in a bilateral "Treaty of Good Neighborly Friendship and Cooperation" in July, 2001 in Moscow.

79. One of the levels of Grossraum analysis that needs to be addressed is the differences in kind between the international relations between "leadings powers" and other interstate dealings. For example, both China and Russia maintain independent relations with other "leading powers," such as the USA. China has tended to refer to its purely bilateral engagements with the Central Asian states as "SCO projects" or initiatives. ${ }^{163}$ And arguably this flexibility can contribute further to both balancing operations and the mitigation of internal tensions between say, China and Russia as both are free to pursue both individual national interests as well as those of the SCO as a whole. ${ }^{164}$ In addition, Russia in particular, has succeeded in displacing possible rival central Asian regional bodies, including by merging the Central Asian Cooperation Organisation, with the Eurasian Economic Council, dominated by Russia itself. ${ }^{165}$ Other such "consolidations" may well take place in the future.

80. China's presence in Central Asia is comparatively new and was made possible by the disintegration of the USSR, which insisted that the three former Soviet republicsKazakhstan, Kyrgyzstan and Tajikistan - were incapable of establishing bilateral relations with China despite sharing borders on its western side. The recent independence of these republics allowed a process of directly dealing with some of them as part of the border negotiations with Russia that culminated in the creation of the SCO. Yet, there is, of course, an inherent asymmetry between the economic, political and military power of China and Russia and the Central Asian states collectively on various fronts

162 Arno Hessbruegge, The Shanghai Cooperation Organisation: A Holy Alliance for Central Asia? (http://fletcher.tufts.edu/Al-Nakhlah/Archives/ / media/Fletcher/ Microsites/al\%20Nakhlah/archives/pdfs/hessbruegge\%202.pdf).

163 Cooley, above n.3, 79.

164 Bailes and Dunay, above n.71, 28.

165 Maksutov, above n.12, 9. 
that could determine the role and future development of the SCO. Furthermore, these Central Asian states have been characterised by ethnic rivalries, a lack of capital, territorial disputes, religious fundamentalism and nationalism. ${ }^{166}$

81. China's involvement in Central Asia region and its promotion of the SCO forms part of its grand geopolitical strategy aimed at shaping the regional order in the longterm. Through its status as a "leading power" within the SCO, which is the only regional body that China has helped create and fully embraced it projects an image of itself to the world as a great - yet responsible and benign — regional superpower with a distinctive and alternative worldview to the US. Arguably, China has demonstrated both the political will and material capabilities to take on a leadership role both immediately within the SCO region considered as its zone of special influence and-in a mediated way-more generally.

82. There is some albeit limited empirical evidence that we are witnessing a move towards an embryonic federal super-state, in which both China and Russia will play increasingly decisive roles; ${ }^{167}$ whilst also taking on greater obligations towards the economic well-being and security of the other SCO members. Although China may give a higher priority to the economic dimension of integration than Russia, whose priorities appear to be more security related, ${ }^{168}$ this is not necessarily evidence of a fracture within the SCO. ${ }^{169}$ Instead, it could be regarded as a useful division of labour between two "leading powers" operating in tandem, with a degree of compromise and avoidance of open conflict that further contributes to regional stability. ${ }^{170}$ On the other hand,

166 Zhang Xiaodong, Central Asia on the Rise, 35 Beijing Review (1992), 12-13. There has been traditional rivalry between Kazakhstan, Tajikistan, and Kyrgyzstan on one side, and a potentially expansionist Uzbekistan on the other. Uzbekistan has had border disputes with the other Central Asian states.

167 Chien Chung, China and the Institutionalization of the Shanghai Cooperation Organization, 53(5) Problems of Post-Communism (2006), 3-14-noting that: Beijing will support institutionalization efforts that foster regional integration and security (abstract); Sznajder, China's Shanghai Cooperation Organisation Strategy, 5 Journal of IPS (2006), 93-102.

168 See Cooley, Cooperation Gets Shanghaied: China, Russia, and the SCO, 12 Foreign Affairs, 14 December 2009, (www.foreignaffairs.com/articles/65724/alexandercooley/cooperation-gets-shanghaied?page=show). This important study highlights tensions between the agendas of the SCO's leadings powers.

169 However, some writers argue that prospects of Sino-Russian competition in Central Asia as a separate pattern of present dynamics within the SCO regional. See Phunchok Stobdan, Shanghai Cooperation Organization: challenges to China's leadership, 4 (32) Strategic Analysis (2008), 527-547.

170 Boland, above n.6, 18 - who notes that even a more fully developed regional bloc such as the EU combines differences of emphasis and priorities, e.g., over Turkish membership. In addition, SCO summits have provided forum for some compromise over conflicts between the South Asian members over water power, again contributing to stability, although further work will be need to resolve energy issues. Ibid.18-19 
Russia has long regarded Central Asia as falling within its spatial zone of privileged interests seeking to embed Central Asia states into a system of Russia-controlled institutions the CSTO; the Eurasian Economic Community (EurAsEC), a customs union and the Commonwealth of Independent States (CIS). Yet China uses the SCO to project its national influence across Central Asia. Russia has blocked many efforts to deepen economic integration such as Chinese proposals to create an SCO free-trade area prefering to champion the expansion of EurAsEC, which includes Russia, Kazakhstan, Kyrgyzstan, Tajikistan, and Belarus but not China.

\section{IV,E. Integration through Economic Cooperation}

83. SCO members appear to recognise that economic security and political stability are closely linked with economic development and that regional cooperation is an important ingredient for regional economic development. The SCO has an ambitious economic integration agenda, including the creation of a free-trade zone and a set of rules for the free movement of goods, services and technologies. Indeed, it has deliberately sought to "deepen economic ties with one another in the economic field". ${ }^{171}$ The SCO is acting to remove obstacles to trade, generating funding for investment in development projects (particularly for infrastructure transport), while also simplifying procedures for banking operations among member-states. One similarity with the EU Grossraum is a commitment to enhance material forms of regional integration by removing impediments to certain types of economic planning, organisation and development, including internal trade. ${ }^{172}$ Here, the aim is to both increase overall economic activity and wealth, and help to solidify the perceived benefits to the regional framework itself through demonstrating material gains to citizens of SCO states. ${ }^{173}$

84. The Tashkent Declaration of Heads of member States of July, 17, 2004, set out timelines for creating SCO Development Fund and SCQ Business Council, as well as addressing a range of economic issues. These included enhanced multilateral trade and economic cooperation, modernizing trade and economic cooperation, increasing

171 Ibid. 15.

172 Most recently, see Xi makes four-point proposal for SCO development, Xinhua September 13, 2014 (www.shanghaidaily.com/national/Xi-makes-fourpointproposal-for-SCO-development/shdaily.shtml) This proposed enhancing "the goal of common development and prosperity" through "conducting more extensive and higher level cooperation in trade and investment, in a bid to push forward regional economic integration." Xi urged SCO member states to reach an agreement on establishing the SCO financial institution at an early date and beef up policy coordination on energy and food, and to enact an SCO partnership plan in science and technology, and to speed up the building of an information sharing platform on environment protection. Ibid.

173 (news.xinhuanet.com/fortune/2009-10/14/content_12233321.htm); SCO Economic Cooperation Programme to be Filled with "Live Projects," 12 September 2008 (www.bc-sco.org/?level=10\&id=532\&lng=en). 
productivity, harmonizing legal and other standards, creating favourable conditions for free movement of goods, capitals, services and technologies, and building transport links. ${ }^{174}$ The June 2006 Shanghai summit established new economic bodies including the SCO Banking Consortium and the Moscow-based Business Council. The latter organises a SCO joint investment programme relating to major infrastructure projects, transport, energy, telecoms and cross-border trade. ${ }^{175}$

85. Certainly, there are increasing agreements over security and economic ties, removal of restraints and tariffs on cross-border trade and investment and banking. At the 2007 SCO summit, Iranian Vice President Parviz Davudi stated that the SCO: "is a good venue for designing a new banking system which is independent from international banking systems." ${ }^{176}$ In 2009, the SCO established an Interbank Association/Consortium, which is linked to the wider Business Council. ${ }^{177}$ This is not (or not yet) a SCO central bank akin to that of the EU. ${ }^{178}$ The address by Putin also included these comments: "We now clearly see the defectiveness of the monopoly in world finance and the policy of economic selfishness. To solve the current problem Russia will take part in changing the global financial structure so that it will be able to guarantee stability and prosperity in the world and to ensure progress". ${ }^{179}$ SCO members have sought benefit from greater integration with China's booming economy. Yet, there is also the prospect that in their trade with China their own domestic markets will be swamped by more completive Chinese goods damaging their national business interests. Furthermore, the SCO still lacks agreed region-wide procedures for commercial arbitration, mediation and dispute settlement procedures, including enforcement procedures through, say, SCO courts and tribunals. In this respect, the high priority afforded to national sovereignty largely restricts economic integration within a firmly intergovernmental format.

174 (http://xn—jtbhwghdp7a.xn-p1ai/data/resources/Tashkent_Declaration_\%20July \%2017_\%202004.pdf). See also The Joint Communiqué of the Moscow Meeting of the Council of Heads of Government of SCO Member States, issued on 26 October 2005 that includes enhanced integration of investment policies as well as energy, transport, telecommunications, science, technology and agriculture.

175 The Interbank Consortium of the Shanghai Cooperation Organisation, 16 March 2009 (www.sectsco.org/EN/show.asp?id=51).

176 Mehr News Agency, October 31, 2008.

177 The Interbank Consortium of the Shanghai Cooperation Organisation, 16 March 2009 (www.sectsco.org/EN/show.asp?id=51); Speech of the SCO SecretaryGeneral B. Nurgaliev at the Economic Conference Under the Auspices of the SCO Business Council and Interbank Consortium, 6 May 2009 (www.sectsco.org/EN/ show.asp?id=82).

178 Boland, n.6 above, 8.

179 Ibid. 


\section{IV.G. The SCO's foreign policies and relations with other regional Grossräume}

86. Grossraum analysis claims that international law has to regulate inter-Grossraum relations in a manner that is consistent with pluralistic principles. These include a prohibition on extra-regional military and other interventions that are perceived as threats to regional autonomy. This is related to the idea of a multi-polar ordering in which no single universal truth about the nature of legitimate governance supposedly applicable everywhere in the world, can ever be accepted. Indeed, the SCO has stated that it's regional: "model of social development should not be 'exported" that: "differences in cultural traditions, political and social systems, values and model of development formed in the course of history should not be taken as pretexts to interfere in other countries' internal affairs". ${ }^{181}$

87. As discussed, a Grossraum is also outward facing. For the SCO, it is the Minister of Foreign Affairs of the member state where the regular meetings of the Council of Heads of State takes place who is responsible for representing the organisation in its external affairs. In addition, the Chairman of the Council of National Coordinators may, on the instruction of this Minister, act on behalf of the SCO in external affairs. ${ }^{182}$ The reaction of the SCO to US troops in South Asia provides a clear instance of this Grossraum element. As Dadabaev recognises:

Another feature of the emerging SCO identity is closely linked to the anticolonial nature of the organisation and can be referred to as its anti-imperial agenda. The SCO strongly reacted to the presence of foreign troops in CA. Especially notable were its persistent calls in 2005 for the removal of foreign troops from the region.... which most of these countries fear could turn into 'political mentorship', imposing the US values of democracy and paths of economic and political development-an imposition that these governments appear to resent at the moment. The role played by the US in its support of an anti-governmental uprising in Kyrgyzstan and the severe US criticism of the government's actions in Uzbekistan in 2005 serve as evidence, whether real or perceived, for many of these governments that, once the US establishes its military or logistic presence in the region, it might be tempted to interfere in the internal affairs of these states. ${ }^{183}$

180 Declaration on the Fifth Anniversary of the Shanghai Cooperation Organization (www.china.org.cn/english/features/meeting/171589.htm).

181 Ibid; Dadabaev, above n.65, 13.

182 Under Arts. $7 \& 9$ of the SCO Charter, the representation undertaken by both should be in accordance with the Rules of Procedure of the Council and the Rules of Procedure of the Council of National Coordinators.

183 Dadabaev, above n.65, 12. 
88. It is arguable that a more fully developed multipolar international order will have to formalise a series of principles applying between Grossraume, particularly as their "leading powers", will inevitably seek to influence developments relevant to the interior space of their region. ${ }^{184}$ One device for this is to ensure that a regional entity has legal personality in its own right. First, however, it is necessary to clarify the sense in which the SCO needs to be recognised as a distinctive transnational entity, with international law standing at least equivalent to that of a state. Although also relevant to some aspects of internal governance, the SCO has already achieved a distinct institutional identity, founded upon law. It now exhibits a distinctive-if still institutionally unaccountable-form of sovereignty within the region. This is grounded in consensual decision-making, but is located over and above that of the member states considered atomistically.

89. Interestingly, the SCO has evolved for itself a form of legal personality and legal capacity, which renders it a "subject" of international law with a range of distinctive legal rights and responsibilities including-as is vital for any Grossraum internal intervention within the territories of each Member State. For example Art. 15 of the SCO Charter states:

It shall have such a legal capacity in the territory of each Member State, which is required to achieve its goals and objectives [and] shall enjoy the rights of a legal person and may in particular: conclude treaties; acquire movable and immovable property and dispose of it; appear in court as litigant; open accounts and have monetary transactions made.

Arguably, this legal status is broadly akin to that of a federal government within a loosely federated state. For example Art. 15 uses the imperative "shall," as opposed to the permissive term "may", when it states:

The decisions taken by the SCO bodies shall be implemented by the member States in accordance with the procedures set out in their national legislation. Control of the compliance with obligations of the member States to implement this Charter, other agreements and decisions adopted within SCO shall be exercised by the SCO bodies within their competence.

90. However, it is important not to overstate this point. For example, it does not rule out selective implementation where different member states have divergent constitutional and legislative arrangements. ${ }^{185}$ Also, not all decisions made by the SCO have "direct effect" within each member state in that mere "recommendations" are not even formally binding. ${ }^{186}$ And here there is an interesting point of

184 Maksutov, above n.12, 8.

185 Al-Qahtani, above n.30, 141.

186 Ibid 141. 
comparison with the EU where only some of EU decisions have such "direct effect". 187

91. In addition, although "supervised" by SCO bodies, the detailed implementation of SCO policies is reserved to the national legislative arrangements of each member. In turn, this allows for a measure of both flexibility and possibly patchy implementation, with some states "ahead" of others on specific measures, a feature noticeable within the EU as well. ${ }^{188}$ On the other hand, there are provisions for both suspension and expulsion of member states that persistently refuse to implement SCO decisions. ${ }^{189}$

92. In terms of foreign affairs, the SCO's claimed achievements include "international outreach areas". ${ }^{190}$ In turn, this will mean that the EU and NATO need to take seriously their bilateral relations with the SCO as an Asian counterpart regional organisation that counterbalances US-Western interests, ${ }^{191}$ together with the impact of inter-Grossraum relations upon their strategic interests. ${ }^{192}$ Partly to improve

187 The provisions of Union law may, if appropriately framed, confer rights on individuals which the courts of member states of the European Union are bound to recognise and enforce. Not explicitly stated in any of the EU Treaties, the principle of direct effect was first established in relation to provisions of those treaties by the European Court of Justice (ECJ) in Van Gend en Loos v. Nederlandse Administratie der Belastingen. Case 26/62); [1963] ECR 1; [1970] CMLR 1. For a discussion see Grahame Robert Anderson, Do unimplemented European Community directives have direct effect - or any other legal effect - in national law? Is the law in this area satisfactory? (www.lepetitjuriste.fr/english-law/c89-english-law/do-unimplemented-europeancommunity-directives-have-direct-effect-or-any-other-legal-effect-in-national-lawis-the-law-in-this-area-satisfactory).

188 Al-Qahtani, above n.30 141.

189 See SCO Charter Art. 13. This type of provision is common in regional bodies, see Art.7 of the Pact of League of Arab States, and more generally Konstantinos D. Magliveras, Expulsion from Participation in International Organizations: The Law and the Practice behind Member States' Expulsion and Suspension of Membership (1999); Michael Akehurst, Enforcement Action by Regional Agencies, with Special Reference to the Organization of American States, 42 BYBIL (1967), 175, 195-6.

190 Boland, above n.6, 11. From 2009, there have recently been some preliminary of high level "interactions" between the SCO's Secretary General with NATO. NATO Press Conference, 25 Jun. 2009 :. (http://www.nato.int/cps/en/natohq/ opinions_55940.htm?selectedLocale=en). In 2010, NATO consolidated this preference. See NATO 2020: Assured Security; Dynamic Engagement Analysis and Recommendations of the Group of Experts on a New Strategic Concept for NATO, 17 May 2010 (www.nato.int/cps/en/natohq/official_texts_63654.htm? selectedLocale=en); The Future of the Atlantic Alliance, Speech by NATO Secretary General Jaap de Hoop Scheffer at Chatham House, London, 20 July 2009 (www. nato.int/cps/en/natohq/opinions_56498.htm?selectedLocale=en).

191 Stephen Aris, Russian-Chinese Relations through the Lens of the SCO, 34 Russie. 34 Nei Visions (2008): (http://ifri.org/files/Russie/Ifri_RNV_Aris_SCO_Eng.pdf). 
Central Asia's economic competitiveness in a globalised world, the SCO has supported the opening of new trade corridors between the PRC and Kyrgyzstan (Irkeshtam Road) and Tajikistan (Khulma Road) respectively. Russia and the PRC have also cooperated with the EU to connect the Central Asian republics with Europe through a road network (TRACEA route) via the Caucasus. ${ }^{193}$ Writing from a US perspective, Boland concludes that there are both strategic benefits and dangers of inter-Grossraum relations with the SCO, and these demonstrate the need to consider mutual influence and impact within a wider global balance of power:

Policy on such a relationship has the potential to impact important U.S. interests, such as a rising China, the Russian reset, and unstable regimes throughout the SCO region. But the risks to the U.S. of appearing to endorse repressive regimes, or of being rejected, sidelined, or negatively used by the group are real and require serious consideration. ${ }^{194}$

93. In terms of external foreign policy, the SCO endorses the characteristic Grossraum commitment to the doctrine of extra-regional non-interference considered as part of a distinctly pluralistic notion of "democratisation" contrasting markedly, perhaps polemically, with US-centric "liberal democracy," 195 According to Cooley, China's co-creation of the SCO as a pluralistic, or multi-polar, initiative broadly akin to a Grossraum represents a firm and decisive rejection of a unipolar international order dominated by the USA where there are no recognised constraints upon intervention arising from established legal doctrines of national sovereignty:

Aris also emphasises the positive side of the mutually reinforcing relationship the SCO has helped solididy between the SCO's twin leading powers.

192 On this point, Maksutov, above n.12, 8 who specifically refers to: "the belief in a multipolar world". See also Oksana Antonenko, The EU Should Not Ignore the Shanghai Cooperation Organisation, Centre for European Reform.; which concludes: "The EU must not ignore the SCO, or fail to acknowledge its growing role in Central Asia. The EU should ... recognise its contribution to regional stability and development. ... It should recognise that all the Central Asian states view the SCO as a positive and important vehicle for their own long-term interests. In the long run, without dialogue with the SCO, the EU is unlikely to fulfil its own potential in the region". Ibid. Cf. Alyson J. K. Bailes, The Shanghai Cooperation Organisation and Europe, 5(3) China and Eurasia Forum Quarterly (2007), 13-18.

193 Jörg Gertel and Richard Le Heron (eds.) Economic Spaces of Pastoral Production and Commodity Systems: Markets and Livelihoods (2011), 189.

194 Boland, above n.6, 49; Troitskiy, above n 47, 44.

195 The SCO's Establishment Declaration para. 5 commits all members to: "the principles of mutual respect for independence, sovereignty and territorial integrity, equal rights and mutual advantage, resolution of all issues through joint consultations, non-interference in internal affairs, non-use or threat of use of military force, and renunciation of unilateral military advantage in contiguous areas". (http://news. xinhuanet.com/english/2003-05/27/content_889169.htm). 
From its founding, the SCO has emphasized two principles that distinguish it from Western-dominated multilateral organizations. First, [...] the SCO charter and public statements repeatedly underscore that it respects its members' sovereignty and rejects interference in their domestic affairs. This can be contrasted with the economic conditionality imposed by Western donors (World Bank, IMF), the human rights criteria or political conditions of Western-led security organizations (NATO, OSCE human dimension), and the growth of the "responsibility to protect" norm, used to justify NATO's military actions in Kosovo and Libya [...] Second, the organization's official documents are littered with references to rejecting "unilateral military solutions," a clear reference to the United States, and promoting the "democratization of international relations," multipolarity, and a new "cooperative spirit". Some Western commentators have interpreted the repeated references to the "Shanghai Spirit" as intentionally opposing the West. ${ }^{196}$

94. We would emphasise that these elements of a new regional organisation that is neither controlled by, nor beholden to, Western interests and inputs, reiterate in a nutshell many of the key commitments of Grossraum analysis, including the polemical deployment of axiomatic political ideas. ${ }^{197}$ This interpretation, which we endorse, stands opposed to the Western fear that China as a superpower aims to achieve world domination. On the contrary, it suggests rather that this regional superpower is content to positively contribute to, and operate within, an emphatically pluralistic multipolar order, and help secure this order's overall equilibrium through a process of "balancing". 198

95. The SCO members' shared interest in achieving a successful SCO has led this organisation to prioritise securing recognition and partnership from other international organisations and multilateral institutions. ${ }^{199}$ The SCO Charter outlines its relationship with other states and international organisations specifying that this regional body may interact and maintain dialogue with both other States and international organisations in certain specified areas of cooperation. Under Art. 14 of the SCO Charter, such intra-Grossraum commitments do not, however, affect the rights and obligations of each member state under other international treaties in which they participate.

196 Cooley, above n.3, 77.

197 Ibid 78.

198 Maksutov, above n.12, 5-10. For contrasting views on China's emergence, see Edward S. Steinfeld, Playing Our Game: Why China's Rise Doesn't Threaten the West (2010), Cf. the more hostile interpretations of Stefan A. Halper, The Beijing Consensus: How China's Authoritarian Model Will Dominate the Twentyfirst Century (2010); Joshua Kurlantzick, How China's Soft Power Is Transforming the World (2007).

199 Article 2 of the SCO's Charter; Cooley, above n.3, 79. 
96. In November 2002, the SCO Council of Ministers of Foreign Affairs adopted the "Interim Scheme of Relations between the Shanghai Cooperation Organization and Other International Organizations and States," which formally began SCO external relations. This measure authorises the invitation of other international organisations to attend as guests the meeting of the SCO Council of Ministers of Foreign Affairs and diplomatic consultations; whilst for its part the SCO can send representatives to attend similar activities in other extra-regional organisations. ${ }^{200}$ SCO may also grant to a non-member state or international organisation the status of a "dialogue partner" or "observer" on condition it demonstrates respect for sovereignty, territorial integrity and equality of Member States, ${ }^{201}$ and recognises the main goals, principles and actions of the SCO the latter defines as axiomatic. $^{202}$

97. There is, then, evidence of the SCO developing its external intra-Grossräume relations broadly along Grossraum lines oriented towards the vindication of multipolarity. As a distinct entity with legal personality, the SCO has established formal relations with the United Nations, where it is an observer in the General Assembly, ${ }^{203}$ the EU, the Association of Southeast Asian Nations (ASEAN), the Commonwealth of Independent States (CIS), the Asia-Pacific Economic Cooperation Group, the East Asia Summit and the Organisation of Islamic Cooperation. ${ }^{204}$ In November 2005, the SCO established a contact group with Afghanistan, ${ }^{205}$ and there is discussion of

200 Al-Qahtani, above n.30, 145.

201 Regulations on the Status of Dialogue Partner of the Shanghai Cooperation Organization, 28 August 2008 (www.sectsco.org/EN/show.asp?id=64).

202 Al-Qahtani, above n.30, 145. The rules and procedures for granting such a status are established by a special agreement of Member States.

203 See UN GA Resolution 59/48 of 2 December 2004-A/59/PV.65, 12. For a discussion on whether the SCO can be considered as an international "regional organization" within the framework of the Articles 33, 45, 52, 53 and 54 of the UN Charter, see Al-Qahtani, above n.30, 131-134 who concludes that it fulfils the formal requirements. Generally, see Wilfried Remans, The Granting of Observer Status by the General Assembly of the United Nations to the International Federation of Red Cross and Red Crescent Societies, in: Karal Wellens, International LawTheory and Practice: Essays in Honour of Eric Suy (1998), 347-62. For an interview on the significance of SCO representation, see Ruslan Suleimenov, SCO-Important Forum to Find Solutions for Regional Security Challenges, 28 Kazinform, December 2009 (www.inform.kz/eng/article/2223613).

204 Bailes and Dunay, above n.71, 28-29; The Development of SCO's Links with International Organisations in 2007-2008, 31 Dec 2008, (www.sectsco.org/EN/show. asp?id=120; www.sectsco.org/EN123/intercourse.asp).

205 Boland, above n.6, 10-nothing that this connection involves: "an effort to balance the ongoing American and Coalition military presence in Afghanistan". 
future observer status. ${ }^{206}$ In addition, there is the possibility of improving relations with the OSCE and NATO. ${ }^{207}$

98. Also at the Bishkek Summit, the SCO member states expressed concern about the destabilising situation in Afghanistan affecting Central Asia caused by drug trafficking and terrorism. ${ }^{208}$ There remains the question of securing Afghanistan which has not yielded a robust policy response from SCO members. But Feigenbaum states that while individual members of the SCO have played constructive roles in Afghanistan, it is unclear what collective measures the organisation could, in practice, possibly take in this difficult context. ${ }^{209}$

99. The SCO's current development of a common and robust security dimension, which is constantly re-affirmed in SCO summits, might encourage leading Western powers, particularly the dominant USA, and USA-led NATO, to seek further cooperation with this organisation. However, in keeping with the polemic role of the SCO's core political idea, there has clearly been a distinctly polemical — if often codedanti-Western stance. For example, the SCO leadership issue a declaration at the Astana Summit of 2005 demanding a time-table for the US to close its military bases in Central Asia. America's Karshi-Khanabad Air Base is located in southern Uzbekistan close to Tajikistan; while its Manas Air Base is situated just north of Bishkek, Kyrgyzstan. This declaration also strongly rejected SCO observer status for the US. ${ }^{210}$ Nevertheless, the SCO still has, according to the SCO's Secretary General at the time, Zhang Deguang, the potential to become a partner of NATO, at least on issues of mutual interest. ${ }^{211}$ One complication is that all the SCO states apart from China have already agreed some bilateral relations with NATO, but China itself continues to resist this. It has been concerned with the implications of NATO's activities

206 Russia Offers Afghanistan Observer Status in the SCO, Ferghana.news, 14 March 2011 (enews.fergananews.com/news.php?id=2051); Jagannath P. Panda, China or the SCO: Who will supervise Afghanistan? 11(15) China Brief, August 12, 2011 (www.jamestown.org/single/?tx_ttnews\%5Bswords\%5D=8fd5893941d69d0be3f 378576261ae3e\&tx_ttnews\%5Bany_of_the_words\%5D=SCO\%27s\&tx_ttnews \%5Btt_news\%5D=38320\&tx_ttnews\%5BbackPid\%5D=7\&cHash=1a64a66114 ebddc3d2a8fe16a96d2b4c\#.VGiQkI33vp8).

207 Bailes and Dunay, above n.71, 29.

208 CSTO proposes to SCO joint effort on post-conflict Afghanistan, RIA Novosti, 31 July 2007; SCO Bishkek Summit, (http://sputniknews.com/world/20070731/ 70008234.html); Bishkekskaya Deklaratsiya, 16 August 2007 (www.scosummit 2007.org/news/press/148/).

209 For a critical response from Evan A. Feigenbaum, see (www.cfr.org/afghanistan/ sco-role-afghanistan/p18944).

210 Maksutov, above n. 12, 9; . Lionel Beehner ASIA: U.S. Military Bases in Central Asia, July 26, 2005, Council on Foreign Relations: (www.cfr.org/russia-and-central-asia/ asia-us-military-bases-central-asia/p8440).

211 Weitz, above n.114, 43. 
in Asia, particularly - as the non-intervention principle of Grossraum theory would anticipate-those taking place inside the SCO region itself. ${ }^{212}$

100. On the other hand, NATO's Bucharest Summit of 2-4 April 2008 has perhaps made future NATO/SCO cooperation on Afghanistan at least possible in that Russia, Turkmenistan and Uzbekistan each agreed to grant transit rights to NATO over what is, in one sense, SCO "territory". ${ }^{213}$ However, Haas notes some important distinctions between the structures and orientations of these two regional bodies concerned with security issues:

Nevertheless, the SCO still lacks a considerable number of essential elements, which NATO, as a mature security organisation, has, namely an integrated military-political structure with permanent operational headquarters, a rapid reaction force, and continuous political deliberations. Furthermore, an essential difference between the organisational development of the SCO and NATO is the fact that NATO is aimed primarily at external security risks whereas the SCO concentrates strongly on security within the territory covered by its member states. Especially China seems committed for the time being to maintain this situation. ${ }^{214}$

101. There is also the question of whether for the purposes of SCO inter-Grossraum foreign relations NATO itself should be considered in whole or part as a genuine Grossraum, or merely a military organisation dominated by America and its Western Allies, lacking any of the wider features and unifying qualities that render both the EU and increasingly the SCO a Grossraum?

\section{IV.H. Security and geo-political equilibrium}

102. As already discussed, a key element of a viable Grossraum ordering lies in its capacity and willingness to act to positively sustain an equilibrium both internally and externally, i.e., within global intra-Grossräume relations. In numerous places our analysis to date has mentioned the complex of balancing operations taking place within the SCO and its external relations, which-in common with Grossraum imperatives-is not content to play a zero sum game. ${ }^{215}$ Maksutov has suggested that the SCO is

212 De Haas, above n.66, 27; Frans Paul van der Putten, De betekenis van China's opkomst voor de NAVO, Internationale Spectator, July/August 2007, 357. Johannes F. Linn and Oksana Pidufala argue that "For China and Russia, SCO provided a forum for developing a common position on non-intervention by outside powers in the region." The Experience With Regional Economic cooperation: Organizations: Lessons For Central Asia, 12, Brookings Institute, 2008 (http://www.brookings. edu/ / media/research/files/papers/2008/10/carec\%20integration\%20linn/10_ carec_integration_linn.pdf).

213 De Haas, above n.66, 29.

214 Ibid, 30.

215 Bailes and Dunay, above n.71, 27-28. 
engaged in precisely this type of exercise. ${ }^{216}$ Controversially, he suggests that the participation of some SCO states in other regional bodies is significant not as "fragmentation" for the development of equilibrium along Grossraum lines. Such participation includes NATO's Partnership for Peace programme (PFP), the OSCE and even US anti-terrorism initiatives and military bases in the smaller Central Asian members, such as Kyrgyzstan, which has permitted US forces to cross into Afghanistan. ${ }^{217}$

103. To some extent, the SCO has contributed to both an active and constructive "balancing," whilst offsetting to some extent Russia and China's dominant status. ${ }^{218}$ Although the smaller states have to accept the reality of the enhanced power and responsibilities of PRC and Russia, the reward is to benefit from a potential measure of pooled sovereignty and influence within the world stage that would otherwise be denied to them, perhaps even more so than with respect to the smaller states within the EU. ${ }^{219}$ Central Asian governments generally appear to prefer working within the SCO framework, as opposed to the CSTO or the Commonwealth of Independent States (CIS), because they are not dominated by a single country. China's balancing presence contributes to internal SCO balance by reducing concerns of external subordination to Russia, while also giving the Central Asian states more room to manoeuvre. The SCO allows these smaller allows to manage China's growing presence in their region multilaterally with the potential support of Russia, as opposed to dealing with China on a purely bilateral basis.

Here, the significant energy reserves of Kazakhstan give this SCO member a strong negotiating position within both the SCO and more generally, which again contributes to a balance. ${ }^{220}$ Where successful, such "balancing" on security matters in particular is probably beneficial to reducing misunderstandings between the SCO and, say, Western Powers - including the EU and NATO ${ }^{221}$ — as opposed to a situation where each Grossraum cuts itself off from cooperation with others on topics of mutual interest, such as anti-terrorism and regular transnational crime. ${ }^{222}$

104. On the other hand, if taken beyond a certain point, exercises of inter-Grossräume cooperation could challenge the position of the SCO's two "leading powers" in ways that themselves generate intra-Grossraum tensions. However, others have argued that one of the overall successes of the SCO has been in:

216 Maksutov, above n.12, 5-10, 12-13.

217 Bailes and Dunay, above n.71, 28.

218 Maksutov, above n.12, 6.

219 Boland, above n.6, 24.

220 Maksutov, above n.12, 9.

221 Russia, Kazakhstan, Tajikistan, and Uzbekistan have now become "partners" in NATO's Euro-Atlantic Partnership Council (EAPC), which is not to be confused with full NATO membership (www.nato.int/cps/en/natolive/51288.htm).

222 Maksutov, above n.12, 6. 
[A]llowing China and Russia to coexist-and to manage their relations with the central Asian states - without any open confrontation. ... the power of China and Russia within the group is well balanced ... the SCO gives [Central Asian states] symbolic recognition and equality and arguably helps in their global policy of balancing. ${ }^{23}$

105. And yet Russia's invasion of Georgia in 2010 caused concern regarding its commitment to the SCO's core policy of non-intervention. ${ }^{224}$ Despite pressure, Russia failed to gain support from either its strategic CIS or SCO partners, with none of the CIS members recognising the independence of the controlled member states "Abkhazia" and "South Ossetia". Because of China's opposition, all the SCO member states refused to endorse the creation of these supposedly two "independent" republics. ${ }^{225}$

106. There is also the interesting question of whether a Grossraum can have different types (or "baskets") of membership on the economic side from those operating at the security dimension (akin to Norway within the EU), or whether regional integration requires both in tandem?

107. In Central Asia, it appears that the post-Soviet Republics remain confident that it is Russia and China who will play the decisive balancing and organising role in the SCO sufficient to enable regional cooperation without the need for any significant negotiations among the Republics themselves. Central Asian analyst Allison argues that: "one explanation for Central Asian leaders' interest in these macro-regional groupings is the need to manage tensions within the Central Asian security sub-complex.... From this perspective, meetings in the EAEC, CSTO or SCO have a socializing function, which serve to mitigate tensions between state leaders". ${ }^{226}$ Indeed, the SCO may well offer opportunities for the Central Asian Republics to balance external dependence between its two "leading powers," providing them more room to manoeuvre and leverage to extract the best deal from each of them. ${ }^{227}$ The strategic position of the SCO in a region where the USA had fought wars and its willingness to allow enhanced engagement with the US may help offset and counteract traditional US unilateralism

223 Bailes and Dunay, above n.71, 28.

224 Niklas Swanstrom, Shanghai Cooperation Organization and the Aftermath of the Russian Invasion of Georgia, 6(3) China and Eurasia Forum Quarterly (2008) (www.chinaeurasia.org/images/stories/isdp-cefq/CEFQ200808/scoarg20080837.pdf); and Niklas Swanstrom, Georgia: The Split That Split the SCO, CACI Analyst, 3 Sep 2008 (www.cacianalyst.org/?q=node/4930); Mark Katz, Russia and the Shanghai Cooperation Organization: Moscow's lonely Road from Bishkek to Dushanbe, 32(3) Asian Perspective (2008), 183-187.

225 Annie Jafalian (ed.) Reassessing Security in the South Caucasus: Regional Conflicts and Transformation (2011), 106.

226 Aris, above n.97. See also Roy Allison, Virtual regionalism, regional structures and regime security, 27(2) Central Asia, Central Asian Survey (2008), 188.

227 Aris, above n.97; Maksutov, above n.12; Boland, above n.6, 20-21. 
including that displayed in its military engagement in Iraq, Afghanistan and most recently Syria. As Boland notes, given its recent unilateralism: "the U.S. risks ... being rejected outright by the SCO members, and being sidelined". 228

108. In short, in numerous ways and just by existing and operating in its present form, the SCO can be credited with making a contribution to the vital function within a regionalist order of securing both intra-Grossraum and extra-Grossraum balance that helps offset the possibility of open conflict, even war. ${ }^{229}$ As with the EU, the SCO has, for the most part, successfully contained open conflict between member states. ${ }^{230}$ It continues to set ambitious targets including medium and longterm: "development strategy to promote the well-being of the peoples of SCO states and turn the SCO into a model for regional cooperation organizations". 231

\section{Conclusion}

109. The aim of this study has been to assess both the SCO and Grossraum theory as a possible framework for making sense of latter's distinctly regionalist features, and to seek a critical insights by cross-referencing them. During, the first decade of its existence, the SCO can claim considerable credit for completing its preliminary institutional building, enhancing political, economic and security cooperation between member states, carry out beneficial cooperation in cultural affairs, education, environmental protection and emergency relief, while also rapidly establishing structured interaction with the remainder of the international community. It has also filled the geopolitical and security vacuum in Euro-Asia after the Cold War, and played an important role in stabilising the situation of its regional zone of sovereign influence. Part of this has involved initiating Euro-Asian regional cooperation, thereby altering the traditional operational formula of geopolitics in this part of the world. Furthermore, the SCO has improved both the regional and transregional balances of power, while

228 Boland, above n.6, 5 .

229 Bailes and Dunay, above n.71, 28. For a contrary view arguing that the SCO will develop only economically, see Subhash Kapila, Shanghai Cooperation Organization Heading Toward Strategic Redundancy? Eurasia Review, 12 Oct 2010 (www. eurasiareview.com/201010129037/shanghai-cooperation-organization-headingtoward-strategic-redundancy.html).

230 " [T] $]$ he SCO has been very successful in creating confidence between the members of SCO and has explicitly worked for conflict prevention even though this has not always been effective". Niklas Swanstrom, The Prospects for Multilateral Conflict Prevention and Regional Cooperation in Central Asia, 23(1) Central Asian Survey (2004), 45.

231 See Chinese FM raises five-point proposal on boosting SCO cooperation, Xinhua, August 01, 2014 (http://english.peopledaily.com.cn/n/2014/0801/c908838763615.html). 
also promoting a form of multi-polarization able to contribute to a global equilibrium of power-blocs. ${ }^{232}$

110. Our study has shown that, to a greater or lesser extent, each of the key defining features of a suitably revised Grossraum model can be detected within the practices, rationale and aims of the still unfolding SCO project. However, certain features of this organisation that we have focused upon still provide real challenges to any contextually insensitive and mechanical application of an unreconstructed Grossraum approach to the SCO. These include the reality of two "leading powers," the participation of certain SCO members in non-SCO security and economic organisations such as CSTO leading to a fragmentation of sovereignties, ${ }^{233}$ and an arguable lack of overarching cultural affinities, or at least those that are associated with a "common Asian identity" capable of assisting with regional identity-formation. One difficulty in classic Grossraum theory seems to be the assumption that regions will be relatively self-contained and clearly differentiated from all others. And yet the experience of the EU as perhaps the most advanced Grossraum-like entity to date, seems to reveal a contrary message. NATO, rather than the EU, has emerged as the key security institution in the European geostrategic space; while the EU has become the key economic institution governing and maintaining order in the European geoeconomic space. We thus have a more complex and differentiated reality of de facto regionalism than classic Grossraum theory anticipates. ${ }^{234}$ Furthermore, the continued adherence by SCO members to principles and practices of national sovereignty and sovereignty-building places at least temporary limits on the extent to which supranational functions within SCO member states can be further delegated to the regional level, or the acceptability of a SCO equivalent to the powerful EU Commission and Council of Ministers directly legislating for member states within certain agreed fields. In effect, this allows any SCO member to sabotage forward developments through a potentially selfish use of a veto power.

111. In addition, despite stated emphasis on people-to-people exchanges, there has yet to be progressive SCO measures to address minority concerns and clashes between different ethnicities and peoples within SCO member states, even where these transcend internal state borders. Indeed, where these have occurred within member states, there has been no SCO interventions. More generally, the constitutional

232 Most recently these were re-affirmed in the 2014 summit, (www.shanghaidaily.com/ national/Xi-makes-fourpoint-proposal-for-SCO-development/shdaily.shtml).

233 Johannes Linn and Pidufala Oksana, The Experience with Regional Economic Cooperation Organizations: Lessons for Central Asia, Wolfensohn Center for Development Working Paper No. 5, Brookings Institution, October 2008 (http://www. brookings.edu/ / media/research/files/papers/2008/10/carec\%20integration\%20 linn/10_carec_integration_linn.pdf); Boland above n.6, 20.

234 James Sperling; Sean Kay, Victor S. Papacosma (eds.) Limiting Institutions? The Challenge of Eurasian Security Governance (2003), 14. 
representation of distinct peoples seems to remain low on the SCO agenda, but this may, from a Grossraum perspective, reflect the unfinished business of a relative newcomer among regional bodies. ${ }^{235}$ Here, we note that it was not until quite recently that the EU, which was created in 1958 (as the EEC) began to develop any real concern for democratic representation of "peoples" other than-as is the case with the SCO - through their governments.

112. For all these reasons, the SCO can only be classified as a Grossraum, or even as an emerging Grossraum, in a highly qualified sense of a body embodying core qualities and tendencies of this pluralistic model, together with certain discrepant and underdeveloped features, which may over time become less significant. At the same time, our case study cast some critical light on even the most sympathetically reconstruction of a Grossraum model, at least insofar as this is understood as relying upon a blanket rejection of universalism and endorsement of pluralism without limit.

Contrary to Schmitt's apparently blanket critique of universalism, a consistent regionalism must advance its arguments as having a general validity, and claim that doctrines of respect for difference, multipolarity and regional self-determination free of extra-regional interventions by spatially alien powers are not restricted to a given time and place. The critique of universalism is and can only be directed against that subtype that is specifically unilateralist. In turn, this leaves the possibility open, not least for its own foundations, of genuinely universalistic principles of global governance through law and other mechanisms within which multipolarity and pluralism would take their place as strictly relative not absolute phenomenon. However, this level of universalism would have to be largely confined to "thin," formal and general regionalist principles lacking substantive content.

113. Arguably, this conclusion in favour of a qualified pluralism provides one way of reading the SCO's Moscow Declaration of May 28-9 2003 that reaffirmed the need for SCO members to observe and fulfil the main goals and principles of the UN Charter and commonly recognised international law norms, together with the important role of the UN and its Security Council in addressing major international issues. Indeed, the SCO member states accepted that: "one of the main areas of UN work should be preemptive measures to avert conflicts in accordance with the UN Charter and the norms of the international law". This Declaration afforded importance to the early finalization in the UN of the draft International Convention on Nuclear Terrorism and Comprehensive Convention against International Terrorism. Furthermore, the SCO member states have consistently insisted that counter-terrorism policies should be waged not against any faith, individual countries or nationalities but rather on the basis of the norms and principles of international law. Hence, the SCO's substantive pluralism cannot always be contrasted with any type of normative universalism as the Schmittian model requires.

235 Bailes and Dunay, above n.71, 28. 
114. With respect to the SCO's credentials as a possible Grossraum, there are also outstanding issues over the question of whether there must be one or two "leading powers"? Or whether security cooperation is a purely intra-Grossraum concern? Or whether the imperative of "balancing" is better realised through overlapping-as opposed to exclusive-memberships of regional security institutions?

115. While the empirical details of the SCO pose real challenges for aspects of even the most sympathetic reconstruction of Grossraum analysis, they also put wind into the sails of the wider project of seeking out a more viable model of regionalism within international law and relations. Given its recent creation, the SCO has to be credited with making remarkable steps forward towards regional integration advancing along some, but not all, Grossraum lines, and the "leading powers" have succeeded in restraining themselves from overwhelming the smaller central Asian republics. This has been the case even where there have been violent changes of government there: ${ }^{236}$ something that must be taken into account before negative comparisons are made to either the EU or NATO. ${ }^{237}$ There is also growing evidence that, despite many Western writer's premature obituaries for this organisation, the SCO is currently meeting many of its members' core aspirations with no members withdrawing and other states, such as Iran, India and Pakistan, seeking to join as full members. ${ }^{238}$ Despite some inevitable delays and internal disputes over resource allocation, in Boland's words, the SCO is:

[A]ccomplishing its objectives of organizational development, outreach to other multilateral groups, and broadening and deepening its scope of effort in the region ... the SCO has proven it is here to stay, bolstered by the participants' perception of value in association and by the global rise in acceptance of regional actors. $^{239}$

116. Within its first decade, the SCO has clearly developed and refined an organisational structure, expanded its relations with other multilateral institutions, and taken concrete actions to broaden and solidify its economic, political, and security-related impact and

236 Boland, above n.6, 17. A clear contrast to the former Soviet method of dealing with conflicts in its "satellite" states.

237 Cf. Huasheng Zhao, The Shanghai Cooperation Organization at 5: Achievements and Challenges Ahead, 4(3) China and Eurasia Forum Quarterly. Central Asia-Caucasus Institute \& Silk Road Studies Program (2006), 105-123 - doubting whether the SCO can have an extended future.

238 Erica Marat, SCO's International Importance Surges as Iran, Turkmenistan Wish to Join, 4 Eurasia Daily Monitor (2007) 127 noting: “Iran's decision to attend the SCO summit hints at the strengthening of a counter-Western alliance in Eurasia. ... One of the incentives for Iran and Turkmenistan to increase contacts with the SCO is to assume protection from international interference in their domestic affairs, as the organization claims greater influence on its territories to prevent possible external intervention in case of terrorist incidents".

239 Boland, above n.6, 49. 
influence, not least in promoting the wider pluralistic cause of regionalism. ${ }^{240}$ As Urrahman notes: "[I]f the SCO expands and encompasses not only security issues, but also addresses economic and social concerns, then it will be a powerful regional player indeed". 241

117. What is clear is that existing Grossraum tendencies within international relations reject the false alternative of a re-affirmation of traditional interstate approaches on the one hand, versus, on the other, stateless, universalistic orientations with imperialistic implications that have jettisoned spatial differentiations altogether. ${ }^{242}$ For example, it is arguable that there are two strands of objective continuity between the Grossraum concept and the current EU which have yet to be sufficiently appreciated to date. Neil Walker maintains that: "objective continuity and common problematique lies not only in the reconceptualization of international law required by the Grossraum/EU, but also, and relatedly, in the search for a new type of internal governance structures of the Grossraum/EU. The two themes-the external and internal dimensions-are closely related'. ${ }^{243}$

118. At least implicitly, the normative commitment of contemporary Grossraum theory is to a general condition of peaceful equilibrium founded on qualified pluralist doctrine of mutual respect for different cultural traditions the distinction between Grossräume, and unfolding in the context of a collapsing Eurocentric type of international law. ${ }^{244}$ Its polemical opposition to the abstract universalisms of both liberal cosmopolitanism and Marxist-Leninism, which have encouraged spatially-indifferent forms of global interventionism and both military and paramilitary resistance to such extra-regional interference, needs to be understood in this specifically normative context.

119. The various tendencies towards regionalism to which the SCO is both a contributor and beneficiary, are likely to intensify, albeit in perhaps unpredictable ways. $^{245}$ Probably the SCO will need to continue to resist imperialistic pressures without allowing this resistance to overly restrict its capacity for achieving regional self-determination in practice within a developing multipolar global ordering that it

240 Ibid, 4.

241 Fazal Ur-rahman, SCO: problems of enhancing economic cooperation, 12 Eurasia Critic (2008) (www.eurasiacritic.com/articles/sco-problems-enhancing-economiccooperation).

242 Schmitt, above n.7, 109-110.

243 Neil Walker, in: Christian Joerges, Europe a Großraum? Shifting Legal Conceptualisations of the Integration Project, in: Joerges and Ghaleigh, Darker Legacies of Law in Europe: The Shadow of National Socialism and Fascism over Europe and Its Legal Traditions (2003), 77.

244 Alberto Toscano, Carl Schmitt in Beijing: Partisanship, Geopolitics and the Demolition of the Eurocentric world, 11(4) Postcolonial Studies (2008), 422.

245 Boland, above n.6, 4, referring to: "the rising acceptance of regionalism as part of the solution to global challenges". 
both exemplifies and lends additional substantial support to. ${ }^{246}$ This may require an intensification of its relations with other regional bodies, perhaps even the creation of the confederation of such bodies including the $\mathrm{EU}^{247}$ and even NATO, ${ }^{248}$ to run alongside, and perhaps partly displace, the UN's often hopeless interventions. ${ }^{249}$

120 Following our attempted "application" of such theory to issues raised by our SCO case study, we suggest that many core aspects of Schmittian Grossraum analysis finds echoes and verification in different empirical elements of this regional body. However, the correspondence is far from complete and the discrepancies suggest that this theory now need to be substantially revised as a precondition for any credible form of contemporary application within international law scholarship. It is no longer credible to simply reverse the priority US-led hegemonic international law gives firstly to universalistic legal norms over a pluralism of contextually specific ones, and, secondly, a stance of unilateralism at the expense of mulitipolarity predicated on principles of respect for cultural differences.

121. Although it is difficult to be too categorical at this early developmental stage (relative to, say, the EU as a more fully institutionalised Grossraum), but it is possible that we are currently witnessing a phased series of more contingent developments and mixed trends. Here, each tends to integrate the SCO members ever more closely into a wider and ever closer union over the next decades. As Boland's extensive 2011 study concludes: “But now Beijing and Moscow—-the SCO's power playersseemingly have secured their stakes in the organization and its future, and most of the participants appear eager to continue, if not deepen, their role in it". 250

122. Our conclusion is that even the demonstrable deficits of a classical form of Grossraum-style analysis of the SCO remain instructive failures: one that should spur on the wide task of revising this and other theories of regionalism in ways that better match the experience of an increasingly multipolar framework of international relations. We would hope our study would encourage other case studies cross-referring the Grossraum

246 See Joobani, above n.56, who suggests that: "in the context of great power politics in Central Asia, the SCO needs to detach itself from the notion of being an anti-Western entity by not letting external forces define its regional and international goals and changing preferences".

247 Council of the European Union, Joint Progress Report on the Implementation of the EU Strategy for Central Asia, 28 June 2010 (http://register.consilium.europa.eu/ pdf/en/10/st11/st11402.en10.pdf); EU, European Union and Central Asia: Strategy for a New Partnership, (www.consilium.europa.eu/uedocs/cms_data/librairie/ PDF/EU_CtrlAsia_EN-RU.pdf); Council of the EU, Joint Progress Report on the Implementation of the EU Strategy for Central Asia, 28 June 2010, (http:// register.consilium.europa.eu/pdf/en/10/st11/st11402.en10.pdf).

248 Richard Weitz, Building a NATO-SCO Dialogue, European Dialogue, 14 March 2011 (http://eurodialogue.org/Building-a-NATO-SCO-dialogue).

249 European Union and Central Asia: Strategy for a New Partnership, above n.247.

250 Boland, above n.6, 49. 
model with the empirical details of the EU, the African Union, Arab League and the new Eurasian Economic body. Here, additional instructive failures of Grossraum theory to full encompass their structures and rationale without remainder could add up to an overall analytical success. 